(Aus dem physiologischen Institut in Bonn.)

\title{
Fettmast und respiratorischer Quotient ${ }^{1}$ ).
}

Von

\section{Dr. Max Bleibtren.}

(Mit 2 Textfiguren und Tafel III.)

Dass bei der Fettmästung der Thiere als Quelle des angesetzten Körperfettes, abgesehen von den in der Nahrung schon vorhandenen Fetten und Fettsäuren, hauptsächlich und wahrscheinlich ausschliesslich die Kohlehydrate in Betracht kommen, darf heute als eine zweifellos festgestellte Thatsache angesehen werden. Da es sich bei diesem Vorgange um die Umwandlung sauerstoffreicher in sauerstoffarme Moleküle handelt, so muss die Frage entstehen, die schon Liebig ${ }^{2}$ ), der Erste, der die Koblehydrate als Quelle des im Thierkörper neugebildeten Fettes erkannte, sich vorlegte, was bei dieser Umwandlung aus dem überschüssigen Sauerstoff wird. Dass der Sauerstoff als solcher austrete, musste von vornherein als unwahrscheinlich gelten, da er im Moment seines Entstehens hinreichend oxydables Material vorfindet, und so lag denn der Gedanke nahe, dass neben dem in Rede stehenden Reductionsprocess gleichzeitig Oxydationsprocesse verlaufen, die den Sauerstoff für sich in Beschlag nehmen. Thatsächlich hat auch schon Liebig sich den Vorgang in dieser Art vorgestellt, und er gelangte dabei zu der eigenthümlichen Theorie der Fettbildung, die er in seiner "Thierchemie ${ }^{3}$ ) auseinandergesetzt hat; ein Rückblick auf diese Theorie ist auch heute noch von Interesse, weil sie uns einen Einblick in die geschichtliche Entwicklung grundlegender Fragen der Stoffwechsellehre gewährt. Dass

1) Die hauptsächlichsten Ergebnisse dieser Arbeit wurden schon im 56. Bande dieses Archivs S. 464 als vorläufige Mittheilung veröffentlicht. Wegen des langen Verzögerns der ausführlichen Mittheilung, die lediglich durch äussere Umstände bedingt war, bittet der Verfasser die Leser des Archivs um Entschuldigung.

2) Liebig, Thierchemie S. $77 \mathrm{ff}$. - Die Citate beziehen sich auf die 2. Auflage der "Thierchemie". Braunschweig 1843.

3) A. a. 0.

E. Pflüger, Archiv für Physiologie. Bd. 85. 
nur chemische Umsetzungen und zwar Oxydationsprocesse ${ }^{1}$ ) die Quelle aller Wärmebildung im Thierkörper sind, Oxydationsprocesse, bei denen vorwiegend Kohlensäure und Wasser als Verbrennungsproducte entstehen, war Liebig, gegenüber zu jener Zeit immer noch nicht ganz überwundenen anderen Anschauungen, vollkommen klar, ebenso, dass alle Thätigkeiten thierischer Organe in letzter Linie auf diesen Stoffwechselvorgang ${ }^{2}$ ) als Ursache zurückzuführen sind. Die positive Wärmetönung - nach der heutigen Ausdrucksweise -, mit der die Umwandlung kohlenstofthaltiger Bestandtheile des Körpers unter Aufnahme des durch die Respiration gelieferten Sanerstoffes der atmosphärischen Luft und unter Bildung von Kohlensäure und Wasser verläuft, fand durch den berühmten Verfasser der "Thierchemie" ihre vollkommen richtige Würdigung; dass aber neben diesen Processen im Organismus der Thiere auch andere vorkommen, die, wie wir heute sagen, mit negativer Wärmetönung verlaufen, und dass bei complicirteren chemischen Processen, die sich aus Vorgängen mit positiver und negativer Wärmetönung zusammensetzen, die schliesslich gewonnene Wärmemenge durch die algebraische Summe dieser theils positiven, theils negativen Beiträge ausgedrückt wird, das war ein Punkt, der von Li e big, wenigstens zu jener Zeit (1843), nicht hinreichend berücksichtigt wurde. So gelangte er zu der irrthümlichen Ansicht, dass überall, wo im Organismus Oxydationsprocesse stattfinden, die Kohlensäure und Wasser als Endproducte liefern, auch eine der Menge dieser Endproducte entsprechende Wärmemenge gebildet werden müsste. Alle Umsetzungsprocesse, bei denen sich aus Substanzen des Thierkörpers durch Oxydation eine gewisse Menge Kohlensäure und Wasser bildet, sind nach Li ebi g's Meinung von einer ebenso grossen Wärmeentwicklung begleitet, wie wenn sich die entsprechende Menge Kohlenstoff und Wasserstoff direet mit Sauerstoff verbunden hätte ${ }^{3}$ ). Der Wärmeinhalt etwaiger sonstiger bei diesen Umsetzungen gebildeter Körper bleibt dabei unberücksichtigt. Das Maass der gebildeten Koblensäure und des gebildeten Wassers ist nach Liebig gleichzeitig das Maass der gebildeten Wärme. Der Umstand, dass bei Gärungs- und Fäulnissprocessen stets Kohlensäurebildung und Wärmeentwicklung mit ein-

1) Liebig, Thierchemie S. $18 \mathrm{ff}$.

2) Liebig, Thierchemie S. 31.

3) Liebig, Thierchemie S. 83. 
ander verknüpft zu sein pflegen, war für Liebig eine Bestätigung dieser Auffassung. Indessen ist gerade das von Liebig angeführte Beispiel der normalen Traubenzuckergärung geeignet, den Irrthum in seiner Anschauung aufzudecken.

Bei der Traubenzuckergärung entstehen nach der Formel:

$$
\mathrm{C}_{6} \mathrm{H}_{12} \mathrm{O}_{6}=2 \mathrm{C}_{2} \mathrm{H}_{6} \mathrm{O}+2 \mathrm{CO}_{2}
$$

aus $180 \mathrm{~g}$ Traubenzucker $92 \mathrm{~g}$ Aethylalkohol und $88 \mathrm{~g}$ Kohlensäure.

Die Verbrennungswärme des Traubenzuckers ist nach $\mathrm{S}$ to h $\operatorname{man} n^{1}$ ) 3,7426 $\mathrm{W}^{\prime}$, die des Aethylalkohols $7,1836^{2}$ ).

$180 \mathrm{~g}$ Traubenzucker repräsentiren demnach einen Wärmeinhalt von . . . . . . . . . . 673,7 W'.

$92 \mathrm{~g}$ Aethylalkohol einen Wärmeinhalt von $\cdot \therefore \frac{660,9 \mathrm{~W}^{\prime}}{12,8 \mathrm{~W}^{\prime}}$.

Danach verliefe also der Process wirklich mit positiver Wärmetönung; aber die erzeugte Wärmemenge ist so gering, dass sie nahezu in die Fehlergrenze der calorimetrischen Bestimmungen hineinfällt. Die Wärme-Erzeugung macht von dem im Traubenzucker enthaltenen Wärmeinhalt nur $1,9 \%$ aus; der ganze Rest ist in den Alkohol übergegangen. Wenn übrigens bei dem Process der alkoholischen Gärung des Traubenmostes thatsächlich eine geringe Erwärmung beobachtet wird, so ist zu berücksichtigen, dass hier auch die Lösungswärme der erzeugten Producte einen Beitrag liefert.

Li e big berechnet nun die gebildete Wärmemenge aus der Menge der gebildeten Kohlensäure ${ }^{3}$ ) und kommt daher für einen Most, der $16 \%$ Traubenzucker enthält, zu einer Erwärmung, die, vơrausgesetzt, dass die ganze Wärmemenge zur Erwärinung des Mostés verwandt würde, 1651/2. Grad betrüge, - eine Zahl, die mindestens $13 \mathrm{Mal}$ zu gross ist. Denn aus der obigen Formel ist ohne weitere Rechnung klar, dass ein $18 \%$ Traubenzucker enthaltender Most (180 g im Liter) sich bei der Gärung nur um $12,8^{\circ}$ erwärmen würde. Li ebig lässt eben die in den Alkohol übergeführte Wärmemenge unberücksichtigt. ${ }^{4}$ )

1) Journ. f. prakt. Chem. N. F. Bd. 45 S. 310.

2) Nach Favre und Silbermann; für den dampfförmigen Aethylalkohol beträgt die Zahl nach Thomsen 7,4022, citirt nach Stohmann's Zusammenstellung in der Zeitschr. f. physik. Chemie Bd. 6 S. 334.

3) Thierchemie S. 85.

4) Dass eine so hohe Wärme-Entwicklung bei dem Gärungsprocess thatsächlich nicht stattfindet, hat Liebig später eingesehen. Es scheint, dass directe 
Für Li ebig's Ansichten über die Fettbildung ist es von Interesse, dass er sich den Vorgang der Traubenzuckergärung in zwei Phasen verlaufend deulst $^{1}$ ), die wir in den heute üblichen Zeichen so zu schreiben haben:

$$
\text { Erste Phase } 2 \mathrm{C}_{6} \mathrm{H}_{19} \mathrm{O}_{6}+6 \mathrm{H}_{2} \mathrm{O}=6 \mathrm{C}_{2} \mathrm{H}_{6} \mathrm{O}+12 \mathrm{O} \text {. }
$$

Durch diesen Reductionsprocess werden 12 Sauerstoffatome frei, die aber gleich zur Oxydation eines weiteren Zuckermoleküls verwandt werden:

$$
\text { Zweite Phase } \mathrm{C}_{6} \mathrm{H}_{12} \mathrm{O}_{6}+12 \mathrm{O}=6 \mathrm{CO}_{2}+6 \mathrm{H}_{2} \mathrm{O}
$$

Durch diesen Oxydationsprocess werden 6 Moleküle Kohlensäure gebildet und ausserdem ebenso viele Moleküle Wasser, als im ersten Process verbraucht wurden, so dass das Endergebniss in der Form

$$
3 \mathrm{C}_{6} \mathrm{H}_{12} \mathrm{O}_{6}=6 \mathrm{C}_{2} \mathrm{H}_{6} \mathrm{O}+6 \mathrm{CO}_{2}
$$

geschrieben werden kann und somit auf die sonst übliche Vorstellung hinausläuft.

Ganz analog dieser Auffassung der Zuckergärung stellt sich nun Liebig auch die Bildung von Fett aus Kohlehydraten (Stärke) vor. Seine Vorstellung ${ }^{2}$ ) lässt sich durch folgende Formel ausdrücken:

$$
2 \mathrm{C}_{6} \mathrm{H}_{10} \mathrm{O}_{5}=\mathrm{C}_{11} \mathrm{H}_{20} \mathrm{O}+\mathrm{CO}_{2}+\mathrm{O}_{7} \text {. }
$$

$\mathrm{C}_{11} \mathrm{H}_{20} \mathrm{O}$ wird als „nächste empirische Formel des Fettes" angenommen; sie kommt thatsächlich der Zusammensetzung der Thierfette einigermaassen nahe. Die wahre Constitution der Thierfette war zu der Zeit noch unbekannt.

Die sieben frei werdenden Sauerstoffatome werden nun wieder zur Oxydation anderer Kohlehydratmengen benutzt, wobei Kohlensäure und Wasser erzeugt wird. Eine gewisse Menge Stärke wird demnach in Fett, Kohlensäure und Wasser übergeführt, wobei neben-

Versuche von Dubrunfaut über die bei der Alkoholgärung des Zuckers entwìckelte Wärme ihn darüber belehrt haken, dass diese Wärmemenge viel kleiner ist, als er angenommen hatte. In seiner bekannten Abhandlung "Ueber die Gärung und die Quelle der Muskelkraft", Journ. f. prakt. Chem. (1870) [2] Bd. 1 S. 35 und 312 (derselbe Aufsatz auch in Liebig's Annalen Bd. 153), erwähnt er wenigstens, dass nach einer directen Bestimmung ron Dubrunfaut die Wärme, welche bei der Gärung des Zuckers frei wird, nur gleich ist dem achten Theil der Wärme, die durch Verbrennung des in der Kohlensäure enthaltenen Kohlenstoffs erzeugt wird (a. a. O. S. 343 und 350 ).

1) Thierchemie S. 84.

2) Thierchemie S. 78 . 
her, entsprechend der gebildeten Kohlensäure und dem gebildeten Wasser, Wärme entsteht.

Also Ueberführung von Kohlehydraten in sauerstoffarme Substanzen (Reductionsprocess) unter Bildung von Kohlensäure (Oxydationsprocess) und gleichzeitiger Bildung von Wärme ist das, was nach Liebig's Auffassung der Alkoholgärung und der Fettbildung gemeinsam ist. Weil er sich das Maass der dabei gebildeten Wärme auf Grund des oben erwähnten Irrthums als recht gross vorstellte, schrieb er der Wärmebildung beim Fettbildungsprocess eine sehr grosse Bedeutung zu. Die Rolle, welche Liebig die Kohlehydrate im Thierkörper spielen lässt, ist die, dass der reiche Sauerstoffgehalt derselben den Thieren, wenigstens dann, wenn durch die Athmung dem Organismus nicht hinreichend Sauerstoff zugéführt wird, als Sauerstoffquelle für die Unterhaltung des Respirationsprocesses dienen könne. Der Organismus besitzt narh jhm die Fähigkeit, bei Mangel an atmosphärischem Sauerstoff sich dadurch zu helfen, dass er aus den Kohlehylraten den in deuseiben enthaltenen Sauerstoff gewissermaassen herausathmet, wobei nebenbei in Folge dieser Reduction die Kohlehydrate in Fett ungewandelt werden. Die Fettbildung „ersetzt dem thierischen Körper eine gewisse Menge des zu den vitalen Processen unentbehrlichen atnısphärischen Sauerstoffes, und zwar in allen denjenigen Fällen, wo der durch Haut und Lungen eingeathmete Sauerstoff nicht hinreicht, um den vorhandenen und dazu geeigneten Kohlenstoff in Kohlensäure zu verwandeln" ${ }^{\prime 1}$ ) Wenn die Aufgabe der Respiration damit erledigt wäre, dass Sauerstoff aufgenommen und Kohlensäure producirt wird, so wäre gegen diese Auffassung nichts einzuwenden; in Wirklichkeit wird aber von dem thierischen Respirationsprocess gefordert, dass dieser Vorgang der Sauerstoffaufnahme und Kohlensäureproduction mit dem Freiwerden von Kräften verknüpft sei, d. h. mit der Umsetzung von Spannkraft in lebendige Kraft (mit Potentialgefälle). Nun ist es ja sehr wohl denkbar, dass der Uebergang der Kohlehydrate in Fett mit positiver Wärmetönung verläuft, ebenso wie es beim Gärungsprocess der Fall zu sein scheint; abèr ebenso wie hier kann es sich nur darum handeln, dass ein gewisser, vielleicht nur kleiner Theil des Energiegehaltes der Kohlehydrate auf diese Weise zum Vorschein kommt, während der Rest in dem Fett aufgespeichert wird. Nur für jenen Antheil kann Liebig's Auffassung zutreffend genannt werden;

1) Liebig, Thierchemie S. 86 . 
in keinem Falle aber ist die bei der Fettbildung gebildete Kohlensäure als das Maass der gebildeten Wärme anzusehen. Die bei der Fettbildung gebildete Kohlensäure spielt offenbar eine ganz andere Rolle als die sonst heim Respirationsprocess gebildete Kohlensäure; nur die letztere ist stets ein Zeichen von Kraftverbrauch; erstere ist verbunden mit Kraftaufspeicherung.

Wie dem aber auch sei, Liebig hat das grosse Verdienst, für die Erkenntuiss der Entstehung des neugebildeten Fettes aus den Koblehydraten die erste wissenschaftliche Grumdlage geschaffen zu haben, und er befand sich damit in so vollkommener Uebereinstimmung mit der Erfahrung der Landwirthe, dass es kaum verständlich ist, wie diese von ihm begonnene Bewegung wieder rückläufig werden konnte, dergestalt, dass man in der Folgezeit die Kohlehydrate als Quelle thierischen Fettes überhaupt nicht mehr gelten lassen wollte, sondern das Fett aus dem Eiweiss ableitete. Es ist gewiss richtig, dass die Erfahrungsthatsache, dass Thiere unter reichlicher Kohlehydratfütterung viel Fett ansetzen können, nicht genügt, um die Entstehung von Fett aus den Kohlehydraten zu beweisen, und dass sehr genau zu untersuchen war, ob nicht vielleicht der Einfluss der Kohlehydrate nur ein indirecter sei. Indessen sind bei den zu starker Fettbildung geneigten Hausthieren, wie den Schweinen, Gänsen, Schafen etc., wenn sie koblehydratreiche Nahrung im Ueberfuss erhalten, schon die quantitativen Mengen des gebildeten Fettes oft so gross, dass, selbst das Maximum der möglichen Fettbildung aus Eiweiss zugegeben, auf die Kohlehydrate als Quelle des gebildeten Fettes nothwendiger Weise zurückgegriffen werden muss. $\mathrm{Zu}$ diesen Ergebnissen führten denn auch die Arbeiten vieler Forscher, wie von $\mathrm{Wolff}^{1}$ ), Soxhlet ${ }^{2}$ ), B. Schulze ${ }^{2}$ ), Tscherwinsky ${ }^{4}$ ), Chaniewsky ${ }^{5}$ ), Meissl und Strohmer ${ }^{6}$ )

1) จ. Wolff, Zur Frage der Fettbildung im Thierkörper. Landw. Jahrb. 1879 S. 661.

2) Soxhlet, Versuche über die Fettbildung im Thierkörper. Zeitschr. d. landw. Vereins in Bayern. Aug. 1881.

3) B. Schulze, Untersuchingen über die Fettbildung aus Kohlehydraten im Thierkörper. Landw. Jahrb. 1882, 1, S. 57-59.

4) N. Tscherwinsky, Zur Frage über die Fettbildung im thierischen Organismus. Landw. Versuchsstationen Bd. 29 S. 317. 1883.

5) Stanislaus Chaniewsky, Ueber Fettbildung aus Kohlehydraten im Thierorganismus. Zeitschr. f. Biol. Bd. 20 S. 179.1884.

6) Meiss 1 und Strohmer, Ueber die Bildung von Fett aus Kohlehydraten 
u. A. Während die genannten Autoren alle eine Fettbildung aus Eiweiss annehmen, aber zu dem Schlusse kommen, dass neben derselben eine Fettbildung aus Kohlehydraten angenommen werden müsse, konnte $\mathrm{Pflüg} \mathrm{er}^{1}$ ) nachweisen, dass für die - an und für sich gewiss mögliche - Bildung von Fett aus Eiweiss im Thierkörper kein einziger stichhaltiger Beweis vorliegt, dass vielmehr die Kohlehydrate die einzige nach gewiesene Quelle neugebildeten Fettes im thierischen Organismus sind; ebenso wurden die Bedingungen, unter welchen die Ueberführung der Kohlehydrate in Fett stattficdet, von Pflüge $\mathrm{r}^{2}$ ) klargestellt.

Nachdem die Thatsache der Fettbildung aus Kohlehydraten und die Bedingungen für das Eintreten derselben festgestellt worden, drängt sich wieder die Frage auf, die, wie wir sahen, Liebig schon beschäftigte, wie man sich diesen chemisch so merkwürdigen Umbildungsprocess vorzustellen habe. Dass dieser Process eine starke Reductionswirkung voraussetzt, ist klar; dass aber mit dem Reductionsprocess gleichzeitig Oxydationswirkungen verknüpft sind, wie schon Liebig angenommen hatte, darf nach unseren früheren Ausführungen als sehr wahrscheinlich angesehen werden. Ausser Reductions- und Oxydationswirkungen muss aber noch etwas Anderes hinzukommen, nämlich, wie Pflüger bereits im Jahre 1888 darlegte $^{3}$ ), eine erhebliche synthetische Thätigkeit des thierischen Organismus, vermöge deren aus den reducirten Theilen der Kohlehydratmoleküle der Aufbau des Fettmoleküls mit seinen langen Fettsäureketten erfolgt. Wohl nicht, wie Liebig anzunehmen scheint, durch vollständige Reduction des einen Kohlehydratmoleküls unter vollständiger Oxydation des anderen, sondern, wie Pfl üg e $\mathbf{r}^{4}$ ) auseinandersetzt, durch intramolekulare Wanderung des Sauerstoffs inner-

im Thierkörper. Monatshefte f. Chemie Bd. 4 S. 801.1883 (auch Sitzungsber. der k. k. Akademie d. Wissensch. Bd. 88 Abth. 3. Juliheft 1883); ferner Meissl, Untersuchungen über den Stoffwechsel des Schweines. Zeitschr. f. Biol. Bd. 24 S. 63.1886.

1) Pflüger, Ueber die Entstehung von Fett aus Eiweiss im Körper der Thiere. Dieses Archiv Bd. 51 S. 229.1891.

2) Pflüger, Ueber Fleisch- und Fettmästung. Dieses Archiv Bd. 52 S. 1. 1892, sowie: Die Ernährung mit Kohlehydraten und Fleisch oder auch mit Kohlehydraten allein etc. Dieses Archiv Bd. 52 S. 239. 1892.

3) Ueber die synthetischen Processe etc. Dieses Arch. Bd. 42 S. 144.

4) Dieses Archiv Bd. 42 S. 149 und Bd. 52 S. 45. 
halb des Kohlehydratmoleküls, wodurch dasselbe in. einem Theil oxydirt, im anderen reducirt wird, werden wahrscheinlich die reducirten Kohlenstoffketten gebildet, die dann vom Organismus zum Aufbau der Fettsäureketten "gfeichsam zurechtgeschnitten und geeignet zusammengefügt werden" 1 ).

Wie man sich aber den Vorgang auch denken möge, wenn der überschüssige Sauerstoff zu Oxydationsprocessen verwandt wird, so wird man die Oxydationsp roducte nachweisen können, und da die letzteren neben Wasser hauptsächlich aus Kohlensäure bestehen werden, so wird man Kohlensäure gewissermaassen als Nebenproduct bei der Fettbildung vorfinden müssen.

Indessen möchte ich hier darauf hinweisen, dass die Bildung von Kohlensäure bei der Bildung von Fett aus Kohlehydrat denn doch nicht etwas ganz Selbstverständliches ist. Es ist an und für sich keineswegs unmöglich, dass der überschüssige Sauerstoff auch andere Verwendung finden könnte, indem er etwa Producte einer weniger vollständigen Oxydation bildet, die nicht durch die Respirationswege den Organismus verlassen, sondern vielleicht in den sonstigen Ausscheidungen - Harn und Koth - ausgestossen werden oder auch, was nicht einmal so unwahrseheinlich wäre, in den Geweben aufgespeichert werden. Man wird in dieser Beziehung immer daran denken müssen, dass der Sauerstoff stets das Stiefkind der organischen Elementaranalyse ist, indem auf ihn, der immer nur als Rest bestimmt wird, die Fehler aller anderen Bestimmungen sich häufen, so dass wir über den Procentgehalt des Sauerstoffs in den thierischen Geweben und seine Variationen im Stoffwechsel nur mangelhaft unterrichtet sind. Es fehlt aber doch keineswegs an experimentellen Unterlagen für die Annahme einer Sauerstoffaufspeicherung im thierischen Organismus. Erinnern wir uns nur der bekannten Versuche Pflüger's ${ }^{2}$ ), durch die gezeigt wurde, dass der Kaltblüter (Frosch) im vollständig sauerstofffreien Raume, anch nachdem er alle Vorräthe freien Sauerstoffs, die er noch in sich birgt, aufgezehrt hat, noch sehr lange Zeit in unverändertem Maasse fortfährt, Kohlensäure zu produciren, was nur denkbar ist, wenn das Thier über Sauerstoffreserven in seinen Geweben verfügt, die auch dann, wenn kein

1) Dieses Archiv Bd. 42 S. 149.

2) Ueber die physiologische Verbrennung in den lebendigen Organismen. Dieses Archiv Bd. 10 S. 251. 1875; siehe besonders S. $313 \mathrm{ff}$. 
Sauerstoff von aussen mehr zugeführt wird, noch eine Zeit lang für die unveränderte Fortsetzung der Lebensprocesse ausreichen. Da diese Thiere, wenn der Versuch nicht allzu lange gedauert hat, sich wieder vollständig erholen, so werden sie nach einem solchen Versuche ihre aufgebrauchten Sauerstoffreserven in den Geweben wieder füllen. Der Kaltblüter muss also die Eigenschaft haben, variable Mengen von Sauerstoff in seinen Geweben zu enthalten. Dasselbe geht auch aus den sehr bemerkenswerthen Versuchen von Athanasiu ${ }^{1}$ ) hervor, durch die er fand, dass die Frösche zur Winterszeit bei vollständiger Inanition sehr häufig die Einheit nicht unbeträchtlich übersteigende respiratorische Quotienten baben, was schwer anders als durch das Vorhandensein von Sauerstoffreserven zu erklären ist und von dem genannten Forscher auch thatsächlich so erklärt worden ist $^{2}$ ). Greift das Thier diese Reserven an, so muss das den respiratorischen Quotienten natürlich in die Höhe treiben; müssen wir doch in den erwähnten Versuchen Pflüg er's den Fröschen den respiratorischen Quotienten $\infty$ zuschreiben. Es fehlt aber nicht an Versuchen, welche auch bei Säugethieren auf einen variablen Sauerstoffgehalt der Gewebe hinweisen; in noch unveröffentlichten Versuchen fand Argutinsky, wie Pflüger ${ }^{3}$ ) erwähnt, dass die fettund glykogenfrei gedachte Muskelsubstanz des Hundes, wenn sie durch Arbeit stark ermüdet wurde, sauers to ffärmer wird. Hier wurde die Differenz des Sauerstoffgehaltes durch die Elementaranalyse nachgewiesen. Die abnorm niedrigen respiratorischen Quotienten, welche bei winterschlafenden Säugethieren, besonders beim Murmelthier, gefunden wurden, lassen darauf schliessen, dass bei diesen Thieren der Winterschlaf mit einer nicht unbeträchtlichen Sauerstoffanreicherung der Gewebe verbunden sein müsse; es wäre hier wahrscheinlich ein ganz aussichtsvolles Unternehmen, die Differenz im Sauerstoffgehalt der Gewebe elementaranalytisch nachzuweisen, wobei allerdings die methodischen Schwierigkeiten, die Pflüge ${ }^{4}$ ) gelegentlich der Besprechung der oben erwähnten Resultate A rgutinsky's hervorhebt, nicht zu untersehätzen sind.

1) Ueber den Respirationswechsel des Frosches in den verschiedenen Jahreszeiten. Dieses Archiv Bd. 79 S. 400 .

2) 1. c. S. 421 .

3) Dieses Archiv Bd 66 S. 635.

4) Dieses Archiv Bd. 66 S. 635. 
Also, die Möglichkeit, dass der bei der Fettbildung aus Kohlehydraten verfügbar werdende Sauerstoff nicht als Kohlensäure ausgeschieden werde, sondern etwa zur Vermehrung des Sauerstoffgehaltes in den Geweben Verweudung finden könnte, ist nicht ohne Weiteres von der Hand zu weisen. Indessen, sobald man die quantitativen Verhältnisse in's Auge fasst und sich darüber klar wird, wie gross die Sauerstoffmengen sind, welche bei Thieren mit starker Mästungsfähigkeit bei der Umbildung von Kohlehydrat in Fett auf diese Weise untergebracht werden müssten, so sieht man doch bald ein, dass eine derartige Annahme nicht ausreichen würde. Eine Berechnung ergibt nämlich, dass der aufzuspeichernde - oder auch in Harn und Koth mehr auszuscheidende - Sauerstoff an Gewicht nur um etwa $1 / 6$ hinter der Gewichtsmenge des gebildeten Fettes zurückbleiben würde, und das wären Mengen, die, bei starker Fettbildung wenigstens, auch bei oberflächlichster Untersuchung der Aufmerksamkeit nicht eatgangen sein würden.

Darf es somit schon von vornherein als das Wahrscheinlichste angesehen werden, dass die Fettbildung aus Kohlehydraten unter Bildung von Kohlensäure vor sich geht, so musste es doch in hohem Grade wünschenswerth erscheinen, für diesen Vorgang den experimentellen Nachweis zu erbringen. Offenbar muss die Bildung von Fett aus Kohlehydraten, wenn sie in der Weise vor sich geht, dass gleichzeitig Kohlensäure gebildet wird, den respiratorischen Quotienten beeinflussen in der Art, dass zu dem Kohlensäurequantum, welches das Thier, seinem jeweiligen Stoffwechsel entsprechend, aus umgesetzter Năhrung ausscheidet, ein neuer Beitrag aus angesetzter Nahrung, nämlich aus dem zu Fett umgewandelten Kohlehydrat, hinzukommt. Da dieser zweite Beitrag zur ausgeschiedenen Kohlensäure seinen Sauerstoff nicht aus der atmosphärischen Luft, sondern aus dem im Kohlehydrat vorhandenen Sauerstoffvorrath schöpft, so muss der Zähler des respiratorischen Quotienten wachsen, ohne dass der Nenner wächst, also der respiratorische Quotient muss selber wachsen. Fettbildung aus Kohlehydraten wird daher mit einem Anwachsen des respiratorischen Quotienten verbunden sein müssen, und wenn, wie wir wissen, bei Thieren, welche ihren Bedarf zum grössten Theile mit Kohlehydraten decken, der respiratorische Quotient schon ohnehin bei blosser Deckung des Bedarfs gross ist, nämlich sich der Einheit nähert, so wird bei starker Fettbildung aus Koblehydraten dieser Werth noch 
weiter wachsen und die Einheit erheblich übersteigen können. Umgekehrt wird man aber auch das Auftreten abnorm boher Werthe des respiratorischen Quotienten, falls sie bei der Fettbildung aus Kohlehydraten thatsächlich beobachtet werden, als eine sehr werthvolle Bestätigung dafür ansehen dürfen, dass die Bildung von Fett aus Kohlehydraten wirklich unter Kohlensäure-Ausscheidung: vor sich geht.

Es ist nicht ohne Interesse, sich hier zu vergegenwärțigen, wie sich der respiratorische Quotient bei der Fettbildung aus Kohlehydraten verhalten müsste, falls die alte Liebig'sche Auffassung, und wie, falls die von Pflüger vertretene zutreffend wäre. Nach beiden Vorstellungen muss der respiratorische Quotient wachsen; nach der Liebig'schen, weil der Nenner kleiner wird, d. h. der aus der Atmosphäre aufgenommene Sauerstoff sinkt, indem das Thier zum Theil gleichsam auf Kosten des in den Kohlehydraten enthaltenen Sauerstoffs athmet, während die Kohlensäure gleich bleibt; nach der Pflüger'schen, weil der Zähler grösser wird, d. h. die Kohlensäure steigt, indem zu der Menge, welche Ausdruck der augenblicklichen Stoffwechselgrösse des Thieres ist, der Zuwachs aus der Fettbildung hinzukommt. Dass der Versuch hier zu Gunsten der letzteren Auffassung entscheiden wird, darf nach den früheren Ausführungen über das Irrige in Liebig's Auffassung als selbstverständlich vorausgesehen werden: bei Fettmast aus Kohlehydraten dürfen wir ein Ansteigen des respiratorischen Quotienten ohne wesentliche Veränderung der Sauerstoffaufnahme des Thieres erwarten.

Wollen wir die Frage beantworten, welchen Umfang das Steigen des respiratorischen Quotienten in Folge der Fettbildung voraussichtlich annehmen kann, so bedürfen wir dazu der Kenntniss der quantitativen Verhältnisse, die bei dem Processe der Umbildung von Kohlehydraten zu Fett obwalten. Dabei stossen wir aber auf die Schwierigkeit, dass uns über den chemischen Vorgang der Fettbildung aus Kohlehydraten eine nähere Vorstellung fehlt. Indessen können wir uns doch unter gewissen Voraussetzungen eine derartige Vorstellung, wenigstens soweit sie die quantitativen Verhältnisse betrifft, bilden. Man kann nämlich die Frage stellen: wie viel Kohlehydrat ist in minimo erforderlich, um eine gewisse Menge Fett zu bilden, unter der Voraussetzung, dass ausserdem nur Kohlensäure und Wasser gebildet wird? Diese Frage gestattet eine eindeutige Antwort. 
Wir nehmen an, es sollen $100 \mathrm{~g}$ thierisches Fett aus Traubenzucker gebildet werden; um eine bestimmte Vorstellung zu haben, sei dieses Fett Schweinefett. Dasselbe hat nach einer Analyse von Schulze und Reinecke ${ }^{1}$ ) die Zusammensetzung:

$$
\begin{array}{r}
\text { C } 76,54 \text {, } \\
\text { H } 11,94 \text {, } \\
\text { O } 11,52 \text {. }
\end{array}
$$

Um den nöthigen Kohlenstoff für $100 \mathrm{~g}$ Schweinefett, nämlich $76,54 \mathrm{~g}, \mathrm{zu}$ liefern, sind in minimo 191,35 g Traubenzucker erforderlich. Diese enthalten nämlich:

$$
\begin{array}{rll}
76,54 & \mathrm{~g} & \mathrm{C}, \\
12,76 & & \mathrm{H}, \\
102,05 & & \mathrm{O} .
\end{array}
$$

Denken wir uns nun, dass $\mathrm{C}, \mathrm{H}$ und $\mathrm{O}$ dieses Kohlehydrates in $\mathrm{C}, \mathrm{H}$ und $\mathrm{O}$ des Fettes übergehe, so bleibt von $\mathrm{H}$ ein kleiner, von $\mathrm{O}$ aber ein grosser Rest übrig, nämlich $0,8 \geq \mathrm{g} \mathrm{H}$ und $90,53 \mathrm{~g} \mathrm{O}$.

Die $0,82 \mathrm{~g}$ H bilden mit $6,56 \mathrm{~g} 0$ zusammen $7,38 \mathrm{~g}$ Wasser.

Von dem Sauerstoff bleiben dann noch 83,97 g übrig. Diese 83,97 $\mathrm{g}$ Sauerstoff können aber 78,71 g weiteres Kohlehydrat (Traubenzucker) vollständig verbrennen und liefern dabei $47,23 \mathrm{~g}$ Wasser und $115,45 \mathrm{~g}$ Kohlensäure. Man erhält daher Folgendes: (191,35 + 78.71) g Traubenzucker $=100 \mathrm{~g}$ Schweinefett $+(7,38+47,23) \mathrm{g}$ Wasser $+115,45 \mathrm{~g}$ Kohlensäure oder

$$
\begin{aligned}
& 270,06 \mathrm{~g} \text { Traubenzucker }=100 \mathrm{~g} \text { Schweinefett } \\
& +54,61 \mathrm{~g} \text { Wasser }+115,45 \mathrm{~g} \text { Kohlensäure. }
\end{aligned}
$$

So muss das Schlussergebniss des Umbildungsprocesses sein, wenn, unserer Voraussetzung gemäss, die $100 \mathrm{~g}$ Fett aus der kleinstmöglichen Menge Traubenzucker hervorgehen sollen, ohne dass [anderes Bildungsmaterial mit herangezogen und ohne dass] andere Nebenproducte als Wasser und Kohlensäure gebildet werden. Annahme eines anderen Fettes statt Schweinefett ändert die Betrachtung nur unwesentlich.

Auf Grund derselben Erwägung schliesst $\mathrm{Meissl}{ }^{2}$ ) in seiner sehr bemerkenswerthen Abhandlung „Untersuchungen über den Stoffwechsel des Schweines", dass $100 \mathrm{~g}$ Stärke höchstens liefern können: $41,1 \mathrm{~g}$ Fett $+47,5 \mathrm{~g}$ Kohlensäure $+11,4 \mathrm{~g}$ Wasser. Auch Han-

1) Ann. f. Chemie und Pharm. Bd. 142 S. 191.

2) Zeitschr. f. Biol. Bd. 22 S. 142.1886. 
riot $^{1}$ ) folgte wohl bei der Aufstellung seiner Formel für die Fettbildung aus Kohlehydraten demselben Gedankengange; als zu bildendes Fett stellt er sich ein Glycerid vor, dessen drei Valenzen durch verschiedene Fettsäureradicale, nämlich durch die drei Hauptrepräsentanten der thierischen Fettsäuren, Stearinsäure, Palmitinsäure und Oelsäure, gesättigt sind. Dieses hypothetische Fett nemnt er "StearoOleo-Palmitin". Wendet man auf dieses Fett die obige Betrachtung an, so gelangt man zu einer Gleichung, welche die merkwürdige Eigensehaft hat, dass dieselbe, wenn man sich statt $100 \mathrm{~g}$ dieses Fettes 1 Gramm-Molekül desselben gebildet denkt, in molekularen Verhältnissen aufgeht, also eine richtige chemische Gleichung darstellt. Das ist die $\mathrm{Hanriot}$ 'sche Formel:

$$
13 \mathrm{C}_{6} \mathrm{H}_{12} \mathrm{O}_{6}=\mathrm{C}_{55} \mathrm{H}_{104} \mathrm{O}_{6}+23 \mathrm{CO}_{2}+26 \mathrm{H}_{2} \mathrm{O} \text {. }
$$

Der scheinbare Vorzug dieser Gleichung dürfte aber wegfallen, wenn man bedenkt, dass thatsächlich dieses hypothetische Fett nicht existirt, wenigstens nicht bekannt ist, dass vielmehr in Wirklichkeit wechselnde Gemenge aus den Triglyceriden Palmitin, Stearin, Oleïn gebildet werden.

Wenn nun die Bildung des thierischen Fettes nach unserer obigen Formel verläuft, wie steht es mit dem thermischen Charakter dieses Vorganges? Nehmen wir als Verbrennungswärme für $1 \mathrm{~g}$ thierischen Fettes $9,500 \mathrm{~W}^{2}$ ), für $1 \mathrm{~g}$ Dextrose nach Stohmann ${ }^{3}$ ) $3,7426 \mathrm{~W}^{\prime}$, so repräsentiren

$270,06 \mathrm{~g}$ Traubenzucker einen Wärmeinhalt von $1010,7 \mathrm{~W}$, $100 \mathrm{~g}$ Fett einen solchen von . . . . . . $\frac{950,0 \mathrm{~W}^{\prime} ;}{60,7 \mathrm{~W}^{\prime}}$

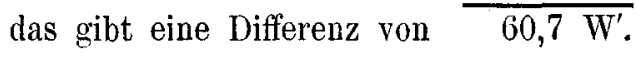

Der Process verläuft also thatsächlich mit einer positiven Wärme. tönung wie die Gärung; der Wärmegewinn ist auch hier kein grosser, beträgt aber immerhin ca. 6\%. Auch Pflüger hat in seiner Arbeit "Ueber Fleisch- und Fettmästung u. s. w." ${ }^{4}$ ) die Erwartung ausgesprochen, dass die in dem Zucker enthaltene Spannkraft nur zum Theil in das gebildete Fett übergehe, und dass daher zur Bildung von $100 \mathrm{~g}$ Fett mehr als $256 \mathrm{~g}$ Traubenzucker er-

1) Compt. rend. vol. 114 p. $371-374$.

2) Nach Stohmann, Zeitschr. f. Biol. 31 S. 377.

3) Journal f. prakt. Chemie N. F. Bd. 45 S. 310 ; siehe auch dieses Archiv Bd. 52 S. 251.

4) Dieses Archiv Bd. 52 S. 45. 
forderlich sei. Unsere Betrachtungsweise ergibt $270 \mathrm{~g}$ als erforderliche Menge.

Nachdem wir über die quantitativen Verhältnisse der von der Fettbildung herrührenden Kohlensäure eine wenigstens unter gewissen Voraussetzungen gültige Vorstellung gewonnen haben, können wir die Frage über das Maass der bei Fettbildung aus Kohlehydraten zu erwartenden Steigerung des respiratorischen Quotienten beantworten. Die Bildung von $100 \mathrm{~g}$ Fett aus Zucker liefert, wie wir sahen, $115,45 \mathrm{~g}$ Kohlensäure. Diese Kohlensäure kommt zu der von dem Thiere, wenn es nur seinen Bedarf deckt, ausgeathmeten Kohlensäure hinzu. Davon, dass der Bedarf des Thieres in Folge der positiven Wärmetönung des Fettbildungsprocesses eine Verminderung erfährt, können wir hier, da der Betrag nur klein ist und es sich nur um eine annähernde Veranschlagung der Werthe handelt, absehen. Ich will diejenige Kohlensäure, welche aus der Fettbildung stammt, die also ihren Sauerstoff nicht, wie beim typischen Athmungsvorgang, aus der athmosphärischen Luft bezieht, der Kürze halber „atypische Kohlensäure" nennen. $100 \mathrm{~g}$ Fettbildung aus Zucker liefern also 115,45 g oder ca. 59 Liter atypische Kohlensäure.

Ein Thier, welches bei einem täglichen Sauerstoffbedarf von 180 Litern $100 \mathrm{~g}$ Fett aus Zucker bildet - dieses Beispiel nähert sich den Verhältnissen bei meinen unten erwähnten Versuchsthieren -, wird durch diese Fettbildung eine Steigerung seines respiratorischen Quotienten gegen den Werth, der bloss der Deckung des Bedarfs entspricht, um $\frac{59}{180}=-0,33$ erfahren. Deckt das Thier seinen Bedarf hauptsächlich mit Kohlehydraten, so dass ohnehin sein respiratorischer Quotient der Einheit nahe liegt, so nähert sich derselbe bei der Fettmästung dem Werthe 1,33. Je grösser die Fettbildung im Verhältniss zum Sauerstoffbedarf ist, um so grösser wird der Zuwachs des respiratorischen Quotienten sein. Die absoluten Werthe, welche derselbe erreicht, werden aber auch noch abhängig sein von dem Material, mit welchem das Thier seinen Bed a $\mathrm{rf}$ deckt. Ist dieses Material Eiweiss mit einem respiratorisehen Quotienten 0,78, so kann schon eine recht erhebliche Fettbildung aus Kohlehydraten stattfinden, ohne dass dadurch der Quotient dauernd über die Einheit hinausgetrieben wird. 
Daraus ergibt sich nun auch, wie man die Versuche einzurichten hat, wenn man möglichst weit über die Einheit hinausgehende respiratorische Quotienten erhalten will; man sieht aus der obigen Berechnung, dass die Fettbildung schon eine recht erhebliche sein muss, um dauernd Werthe bis zu $1,33 \mathrm{zu}$ erhalten. Denn $100 \mathrm{~g}$ Fettbildung bei 180 Litern Sauerstoffbedarf ist eine sehr grosse Menge, d. h. es muss eine im Verhältniss zur Stoffwechselgrösse sehr grosse Fettproduction stattfinden. 180 Liter $=257,5 \mathrm{~g}$ Sauerstoff haben nämlich, wenn wir annehmen, dass das Thier hauptsächlich mit Kohlehydrat (Stärke) seinen Bedarf bestreitet, und wenn wir daher den calorischen Coëfficienten der Stärke $-1 \mathrm{~g}$ Sauerstoff $=3,53 \mathrm{~W}^{\prime}-$ zu Grunde legen ${ }^{1}$ ), ein calorisches Aequivalent von 909 grossen Wärme-Einheiten. $100 \mathrm{~g}$ Fett entsprechen aber 950 grossen WärmeEinheiten. Man sieht daraus, dass das Thier, um zu jenen hohen Werthen des respiratorischen Quotienten gelangen zu können, eine Menge Fett aus Kohlehydraten bilden muss, deren Wärmewerth ca. $105 \%$ seines Bedarfes ausmacht; d. h. mit anderen Worten: das Thier muss eine Kohlehydratzulage von mindestens $100 \%$ zu seinem Erhaltungsfutter bekommen und verarbeiten können! Ausserdem ist noch dazu erforderlich, dass die Thiere ihren Bedarf hauptsächlich mit Kohlehydraten decken. Danach ist es klar, dass von den Thieren nur die Virtuosen in fettbildender Fähigkeit in Betracht kommen können. Unter den Hausthieren sind das die Schweine und Gänse. Schweine konnten wegen der hohen Kosten des dazu erforderlichen Respirationsapparates nicht in Frage kommen. So lenkte denn Herr Professor P flüg er, dem ich die Anregung. zu der vorliegenden Arbeit verdanke, meine Aufmerksamkeit auf die Gänse als geeignete. Versuchsobjecte, und diese haben sich auch für den besagten $Z$ weck vollkommen bewährt.

Die Gänse waren junge, aber ausgewachsene Thiere, die den Sommer über auf der Weide gegangen waren. Ich erhielt dieselben in magerem Zustande und mästete sie darauf in der üblichen Weise durch Zwangsfütterung („Stopfen“) mit Roggenmehlklössen, die am Feuer etwas angebacken waren. Ueber die verfütterten Mengen und die Gewichtszunahme geben folgende Tabellen Aufschluss. Bei der zwangsweisen Fütterung der Thiere mit möglichst grossen Mengen geht unzweifelhaft ein grosser Theil des gereichten Futters im Koth unverdaut wieder ab; der letztere enthielt stets grosse Mengen von Stärkekörnern. Dem

1) Siehe Pflüger, dieses Archiv Bd. 77 S. 465, sowie Bd. 78 S. 526. 
Ma asse der Ausnutzung des Futters wurde aber nicht näher nachgefo rscht, da es mir zuuächst nur darauf ankam, eine möglichst starke Fettbildung aus Kohlehydraten $\mathrm{zu}$ erzielen und während derselben Respirationsversuche anzustellen.

Thier Nr. I.

Gans von $4020 \mathrm{~g}$ Gewicht am Anfang des Versuches.

\begin{tabular}{|c|c|c|c|c|c|}
\hline $\begin{array}{c}\text { Tag } \\
\text { und Jahr } \\
1893\end{array}$ & $\begin{array}{l}\text { Ge- } \\
\text { wicht } \\
\text { in } g\end{array}$ & \begin{tabular}{|c|} 
Zahl \\
der seit der \\
rorigen \\
Wägung \\
verflossenen \\
Tage \\
\end{tabular} & $\begin{array}{c}\mathrm{Zu-} \\
\text { nahme } \\
\text { an } \\
\text { Gewicht }\end{array}$ & $\begin{array}{l}\text { Durch- } \\
\text { schnitt- } \\
\text { liche Zu- } \\
\text { nahme } \\
\text { pro Tag }\end{array}$ & $\begin{array}{l}\text { Bemerkungen üler die } \\
\text { Art der Fütterung }\end{array}$ \\
\hline 28. Oct. & 4020 & - & - & - & \\
\hline 2. Nov. & 4850 & 5 & 330 & 66 & 28. Oct. bis 15 . Noy. $10 \mathrm{~kg}$ Roggen- \\
\hline 7. Nov. & 4550 & j & 200 & 40 & \\
\hline 9. Nov & 4680 & 2 & 130 & 65 & $\begin{array}{l}\text { schnittlich täglich 5os g. Füt- Fut } \\
\text { terung drei Mal täglich mit }\end{array}$ \\
\hline 10. Nov. & 4730 & 1 & $\begin{array}{l}50 \\
50\end{array}$ & 50 & annähernd gleichen Portionen. \\
\hline 13. $\mathrm{No}$ & & 2 & 200 & 100 & \\
\hline 17. Nov. & 5300 & 4 & 320 & 80 & $Y_{0} 01$ \\
\hline 20. Nov. & 5480 & 3 & 180 & 60 & 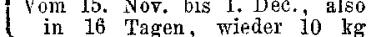 \\
\hline 28. Nov. & 6200 & 8 & 720 & 90 & Roggenmehl verbraue \\
\hline 1. Dec. & 6220 & 3 & 20 & 7 & täglich im Dur \\
\hline 2. Dec. & 62.50 & 1 & 30 & 30 & \\
\hline 3. Dec. & 6290 & 1 & 40 & 40 & \\
\hline 4. Dec. & 6320 & 1 & 30 & 30 & In derselben Weise weiter ge- \\
\hline 6. Dec. & 6480 & 2 & 160 & 80 & fúttert. \\
\hline 7. Dec. & 6600 & 1 & 120 & 120 & \\
\hline 8. Dec. & 6528 & 1 & -77 & -77 & \\
\hline 9. Dec. & 65 & 1 & +47 & +47 & $\begin{array}{l}\text { Vom 9. bis 12. Dec. nur mit der } \\
\text { Hälfte des zuletzt gereichten }\end{array}$ \\
\hline 13. Dec. & 65 & 4 & 0 & 0 & 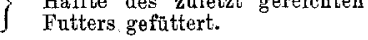 \\
\hline 14. Dec. & 64 & $\frac{1}{1}$ & $\begin{array}{l}-150 \\
-70\end{array}$ & $\begin{array}{l}-130 \\
-70\end{array}$ & \\
\hline $\begin{array}{l}\text { 10. Dec. } \\
\text { 16. Dec. }\end{array}$ & & 1 & -80 & -80 & 13. bis 19. Dec. Hunger. \\
\hline 18. Dec. & 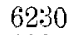 & 2 & -60 & -30 & \\
\hline 19. Dec. & 6090 & 7 & -140 & -140 & \\
\hline & & & +1 & +65 & \\
\hline 20. & & 1 & +80 & +80 & \\
\hline 26. Dec. & 6400 & 4 & +100 & $\begin{array}{l}+25 \\
+\quad 50\end{array}$ & täglich gefüttert. \\
\hline $\begin{array}{l}\text { 20. Dec. } \\
\text { 29. Dec. }\end{array}$ & 65 & 1 & $\begin{array}{r}+100 \\
+\quad 30\end{array}$ & $\begin{array}{l}+\quad 30 \\
+\quad 30\end{array}$ & \\
\hline
\end{tabular}

29. bis 31. Dec. Hunger. Am 31. Dec. wurde das Thier geschlachtet. Es liess sich mit Leichtigkeit $1 \mathrm{~kg}$ Fett aus dem Körper heransschneiden. - Die Wägungen erfolgten stets früh Morgens vor der ersten Fütterung.

$\mathrm{Zu}$ der Tabelle ist zu bemerken, dass natürlich bei der Beurtheilung der Gewichtszunahme nur auf längere Zeiträume etwas zu geben ist. Von Tag zu Tag machen sich ausser den wirklichen Differenzen des Körpergewichts auch zufällige Versehiedenheiten der

1) Die Tage, an denen die Respirationsversuche stattfanden, sind fett gedruckt. 
Darmfüllung, der Wasseraufnabme u. s. w. bemerkbar. In der Zeit vom 28. October bis 9. December nahm das Gewicht des Thieres von 4020 auf $6570 \mathrm{~g}$ zu, also in , 42 Tágen um $2550 \mathrm{~g}$, das ist eine Zunahme gegen das ursprüngliche Gewicht um $63 \%$, wovon allerdings ein Theil auf die grössere Darmfüllung bezogen werden kann. Die tägliche durchschnittliche Zunahme in dieser Zeit ist $61 \mathrm{~g}$. In den vier halben Fasttagen, 9. bis 12. December, behauptet das Thier sein Gewicht mit dem' halben Futter. In den sechs vollständigen Hungertagen nimmt es um $480 \mathrm{~g}$ ab, das ist durchschnittlich täglich $80 \mathrm{~g}$ oder, wenn man den ersten Tag wegen der abnehmenden Darmfüllung ausschliesst, um durchschnittlich täglich $70 \mathrm{~g}$.

Thier Nr. II.

Gans, mager und schmächtig, von $3990 \mathrm{~g}$ Gewicht beim Beginn der Beobachtung.

\begin{tabular}{|c|c|c|c|c|c|}
\hline $\begin{array}{c}\text { Tag } \\
\text { und Jahr } \\
1894\end{array}$ & $\begin{array}{l}\text { Ge- } \\
\text { wicht } \\
\text { in } \mathrm{g}\end{array}$ & \begin{tabular}{|c|} 
Zahl \\
der seit der \\
vorigen \\
Wägung \\
vertlossenen \\
Tage \\
\end{tabular} & $\begin{array}{c}\text { Zu- } \\
\text { nahme } \\
\text { an } \\
\text { Gewicht } \\
\text { in } g\end{array}$ & $\begin{array}{l}\text { Durch- } \\
\text { schnitt- } \\
\text { liche } \mathrm{Zu}- \\
\text { nahme } \\
\text { pro Tag } \\
\text { in g }\end{array}$ & $\begin{array}{l}\text { Bemerkungen über die } \\
\text { Art der Fütterung }\end{array}$ \\
\hline $\begin{array}{l}\text { 6. Jan. } \\
\text { 9. Jan. } \\
\left.\text { 10. Jan. }{ }^{1}\right) \\
\text { 12. Jan. } \\
\text { 14. Jan. } \\
\text { 15. Jan. }\end{array}$ & $\begin{array}{c}3990 \\
3640 \\
- \\
3740 \\
3800 \\
-\end{array}$ & $\begin{array}{l}\frac{-}{3} \\
\frac{2}{2} \\
-\end{array}$ & $\begin{array}{r}-\overline{350} \\
\overline{100} \\
+\quad 60 \\
-\end{array}$ & $\begin{array}{l}-\overline{117} \\
-- \\
+\quad 50 \\
+\quad 30 \\
\end{array}$ & $\begin{array}{l}\text { Hunger. Am Versucbstag, 10. Jan., } \\
\text { Wëgung nicht möglieh, da das } \\
\text { Thier nass war. } \\
\text { 10. bis 12. Jan. Hafer nach Be- } \\
\text { lieben. 12. bis 14. Jan. Beginn } \\
\text { des ntopfens". } \\
\text { Das Thier stirbt beim Stopfen. }\end{array}$ \\
\hline
\end{tabular}

Das Thier, das bestimmt war, später zu Respirationsversuchen im Mästungszustand zu dienen, starb beim "Stopfen" in Folge einer Ruptur des Oesophagus. Glassplitter im Magen und Oesophagus.

Thier Nr. III.

Gans, etwas fetter als Nr. I am Anfang des Versuches. Anfangsgewicht am 20. Januar $18945330 \mathrm{~g}$. Beginn des Stopfens am 21. Januar.

\begin{tabular}{|c|c|c|c|c|c|}
\hline $\begin{array}{c}\text { Tag } \\
\text { und Jahr } \\
1894\end{array}$ & $\begin{array}{l}\text { Ge- } \\
\text { wicht } \\
\text { in } g\end{array}$ & \begin{tabular}{|c|} 
Zahl \\
der seit der \\
vorigen \\
Wägung \\
verflossenen \\
Tage
\end{tabular} & $\begin{array}{c}\text { Zu- } \\
\text { nahme } \\
\text { an } \\
\text { Gewicht } \\
\text { in g }\end{array}$ & $\begin{array}{l}\text { Durch- } \\
\text { schnitt- } \\
\text { liche Zu- } \\
\text { nahme } \\
\text { pro Tag } \\
\text { in } g\end{array}$ & $\begin{array}{c}\text { Bemerkungen über die } \\
\text { Art der Fütterung }\end{array}$ \\
\hline $\begin{array}{l}\text { 20. Jan. } \\
\text { 23. Jan. } \\
\text { 24. Jan. } \\
\text { 25. Jan. } \\
\text { 27. Jan. } \\
\text { 29. Jan. } \\
\text { 31. Jan. }\end{array}$ & $\begin{array}{l}5330 \\
5157 \\
5160 \\
5230 \\
5370 \\
5585 \\
5470\end{array}$ & $\begin{array}{l}\overline{3} \\
1 \\
1 \\
2 \\
2 \\
2\end{array}$ & $\begin{array}{r}-\overline{173} \\
+\quad 3 \\
+\quad 70 \\
+140 \\
+215 \\
-115\end{array}$ & $\begin{array}{r}- \\
-\quad 58 \\
+\quad 3 \\
+\quad 70 \\
+\quad 70 \\
+107 \\
-\quad 58\end{array}$ & $\begin{array}{l}\text { Vom 21. bis } 31 \text {. Jan. im Ganzen } 5 \mathrm{~kg} \\
\text { Roggenmehl verfüttert. In den } \\
\text { ersten Tagen wurde mit ganz } \\
\text { kleinen Mengen begonnen, dann } \\
\text { gesteigert. Fütterung in drei } \\
\text { Portionen taglich. Vom } 29 \text {. bis } \\
\text { 31. Jan. Futter vermindert, da } \\
\text { cnderer Hindernisse halber mit } \\
\text { Respirationsrersuchen noch nicht } \\
\text { begonnen werden konnte. }\end{array}$ \\
\hline
\end{tabular}

1) Die fettgedruckten Zahlen bezeichnen die Versuchstage.

E. P flüg er, Archiv für Physiologie. Bd. 85. 


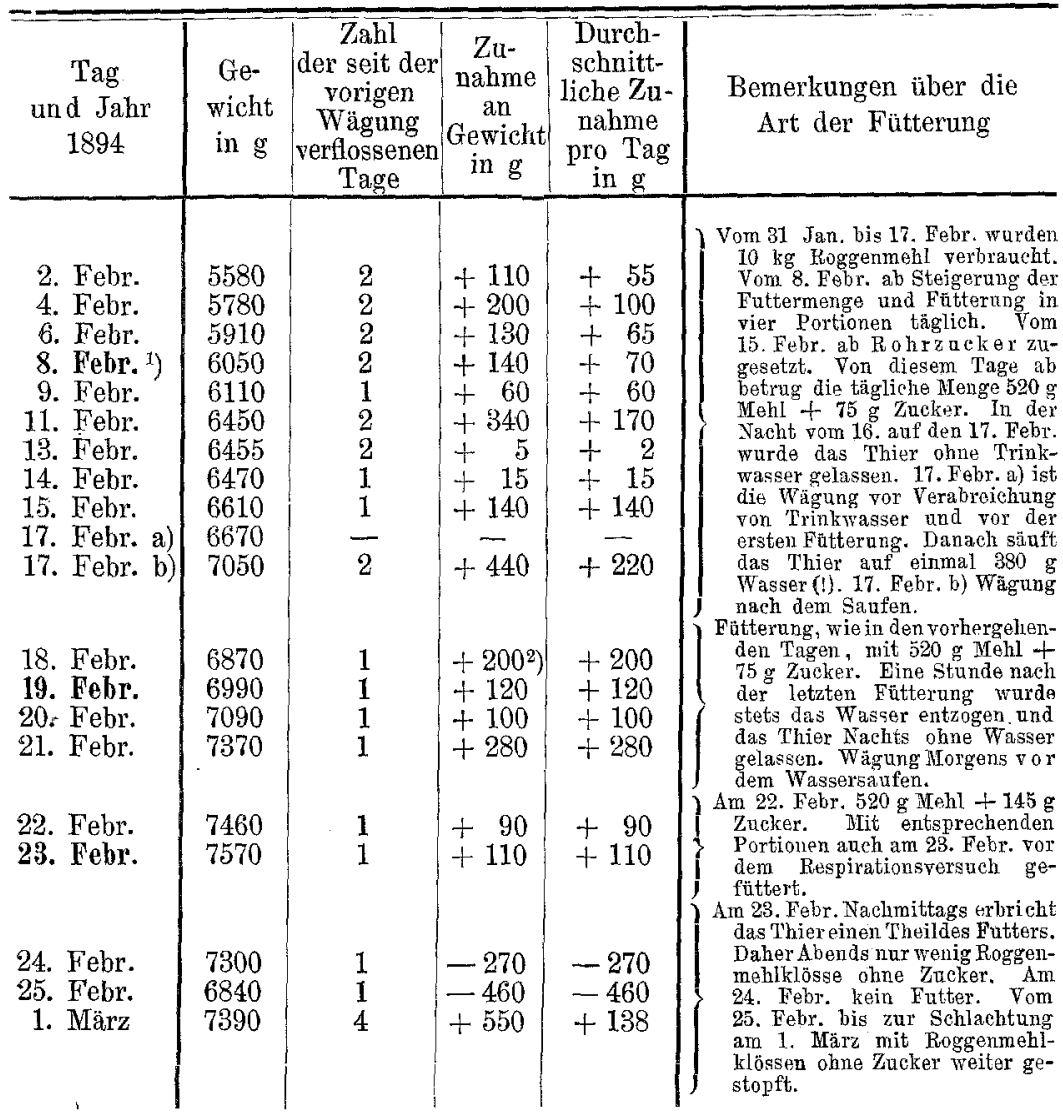

Am 2. März wurde das Thier geschlachtet. Aus Bauchhöhle und Bauchwand wurden $1200 \mathrm{~g}$ Fett herausgeschnitten. Das Gewicht ohne Blut und Federn betrug $6450 \mathrm{~g}$.

Vom 23. Januar bis 23. Februar stieg das Gewicht des Thieres von $5330 \mathrm{~g}$ auf $7570 \mathrm{~g}$, also um $2240 \mathrm{~g}$, d. i. um $42 \%$ des ursprünglichen Gewichtes. Der durchschnittliche tägliche Ansatz beträgt 72 g. Einen wie grossen Einfluss die Wasseraufnahme auf das Körpergewicht haben kann, zeigen die beiden Wägungen a) und b) am 17. Februar. Besonders der Zuckerzusatz zur Nahrung scheint das Wasserbedürfniss des Thieres sebr zu steigern.

Bei beiden gemästeten Thieren Nr. I und Nr. III war ich wohl bis an die Grenze der Mästungsfähigkeit gekommen; es ist bekannt,

1) Die fettgedruckten Zahlen bezeichnen die Versuchstage.

2) Verglichen mit der Wägung 17. Februar a). 
dass die Mastthiere, wenn sie bis zu einem gewissen Grade gemästet sind, nicht mehr weiter oder nur noch wenig an Gewicht zunehmen. Ich war bestrebt, die während der Mästung angestellten Respirationsversuche, je drei bei den Thieren I und III, in die Zeit möglichst grosser und regelmässiger Fettbildung zu verlegen. Ausserdem wurde mit Thier Nr. I ein Respirationsversuch im Hungerzustande angestellt (19. Dezember). Bei dem Thier Nr. III schien um den 11. bis 14. Februar die Fettbildung geringer zu werden; daher wurde das Futterquantum vermehrt, und zwar, um ein leicht und schnell resorbirbares Kohlehydrat zu nehmen, durch Zucker. Das hatte auch thatsächlich eine erneute starke Zunahme zur Folge. Bei der Art der Fütterung darf wohl der grösste Theil der Gewichtszunahme der Thiere auf Fett bezogen werden. Das erste Thier war beim Beginn des Versuches ganz mager; wenn sich am Schluss des Versuches 1 Kilo Fett mit Leichtigkeit, ohne irgend welches Präpariren und Zerlegen, ausschneiden liess, so wird man zugeben, dass von den $2550 \mathrm{~g}$ Gesammtzunahme der grösste Theil Fett gewesen sei. Es ist noch zu beachten, dass die Fettbildung in den Tagesstunden, während die Respirationsversuche gemacht wurden, wahrscheinlich noch grösser war, als durch die tägliche Gewichtszunahme angezeigt wird. Es war zwar das Bestreben, die Thiere in einen möglichst gleichmässigen Mästungszustand zu versetzen, wesshalb das Futter in drei, zum Theil auch in vier Portionen verabreicht wurde. Die Respirationsversuche fanden Nachmittags einige Zeit nach der zweiten bezw. dritten Fütterung statt, während die erste Fütterung frühmorgens vorgenommen wurde, so dass anzunehmen war, dass die Thiere zur Zeit der Respirationsversuche auf dem Höhepunkt der Verdauungsthätigkeit sich befanden. In der Nacht musste aber wohl naturgemäss wegen der längeren Unterbrechung der Futteraufnahme ein gewisses Nachlassen der Verdauungs-, Resorptions- und Assimilationsthätigkeit stattfinden, wenn auch bei der angewandten Ueberfütterung der Darm der Thiere wohl niemals ganz leer wird.

Es möge hier noch eine Beobachtung ihren Platz finden, welche auch von anderen Autoren ${ }^{1}$ ) an gemästeten Gänsen gemacht worden

1) Hoppe-Seyler, Physiol. Chemie 1881 S. 433 . - Ueber milchig getrübtes Serum vgl. auch Gumprecht, Ueber Lipämie. Deutscbe med. Wochenschr. 1894 Nr. 39; ferner Lehmann, Lehrbuch d. physiol. Chemie Bd. 2 S. 174.1859 2. Aufl., Wagner, Handwörterbuch d. Physiologie Bd. 1 S. 125. Braunschweig 1842, Heller, Arch. f. phys. u. pathol. Chemie u. Mikroskopie 1844 
ist: das ist die Beschaffenheit des Blutes der Thiere. Thier Nr. III wurde bis zum Schluss weiter gemästet und im Mästungszustand geschlachtet: Das Blut dieses Thieres hatte eine eigenthümliche Farbe, es war nicht blutroth, sondern etwa wie roter Weinmost aussehend, etwas in's Violett spielend und atlasglänzend; beim Stehen des defibrinirten Blutes setzten sich die Blutörperchen bald $a b$, und es zeigte sich, dass das darüberstehende Serum von milchweisser Farbe und ganz undurchsichtig war. Das Serum hatte auch sonst die Beschaffenheit einer sehr fettreichen Milch. $25 \mathrm{ccm}$ des Blutes ergaben beim Ausschütteln mit Aether, obne vollständig erschöpft zu sein, 1,5315 g Aetherextract d. i. 6,1260\% \% Sicher ist der Fettgehalt des Blutserums noch böher gewesen als diese Zahl. Das Serum hatte also den Charakter einer sehr gehaltreichen Fettemulsion. Wurde das Blut mikroskopisch untersucht, so zeigte sich ein im höchsten Grade überraschender Anblick. Ich hatte erwartet, ausser den Blutkörperchen die Fettkügelchen der Fmulsion zu Gesicht zu bekommen. Statt dessen sah man nur die Blutkörperchen in einem homogenen durchsichtigen Medium. Erst sehr scharfes $\mathrm{Zu}^{-}$ sehen bei starker Vergrösserung (Zeiss E.) liess besonders an Präparaten, die mehr Serum und wenig Blutkörperchen enthielten, erkennen, dass es sich doch um eine Emulsion handelte, indem man feinste Partikelchen in der Zwischenflüssigkeit wie einen dichten Nebel wahrnehmen konnte. Es handelt sich bier um eine Emulsion von solcher Feinbeit, wie ich mich nicht erinnere, sie sonst jemals gesehen zu haben. Ich glaube, dass selbst geübte Mikroskopiker bei oberflächlicher Beobachtung dieser Blutpräparate den Emulsionscharakter des Serums übersehen haben würden. Dieser Gegensatz zwischen dem makroskopischen Aussehen, das sofort auf eine ausgesprochene dicke Emulsion hindeutete, und dem mikroskopischen Anblick, der den Emulsionscharakter erst nach längerem Zusehen erkennen liess, wirkte sehr überraschend. -- Diese Erscheinung einer starken Fettanhäufung im Blute lässt zunächst vermuthen, dass ebenso wie die Gewebe des Thieres auch das Blut an der Fettmästung Antheil nehme. Diese Auffassung wäre jedoch irrig. Bei anderen Gänsen, z. B. bei dem Thier Nr. I, das zwar in hoch-

(Blut mit milchähulichem Serum und einer äusserst grossen Menge Fett bei Peritonis). - Mehrfache andere Literaturangaben auch in der erwähntẹn Arbeit von Gumprecht. 
gemästetem Zustande, aber nach Einschiebung mehrerer Hungertage geschlachtet worden war, verhielt sich das Blut vollkommen normal; das Serum war ganz klar und durchsichtig. Woher stammt nun die merkwürdige Fettanhäufung im Blute während der Fettmästung? Ist es das aus den Kohlehydraten entstandene Fett, welches vielleicht schon im Intestinaltractus diesen Umwandlungsprocess durchgemacht hat und nun, im Blute circulirend, Unterkommen in den Geweben sucht? Ich glaube diese Frage verneinen zu können. Ich habe, da uns die überraschende Erscheinung sehr interessirte, einen Versuch mit einem besonderen Thier gemacht, welches ich, einem Rathe von Herrn Professor Pfl üger folgend, mit möglichst fettfreiem Kohlehydrat mästete. Als reines Kohlehydrat wurde Kartoffelmehl mit Zuckerzusatz genommen, daraus unter Zusatz von etwas Eierklar Klösse gebacken und mit diesen die Gans gestopft. Es gelang thatsächlich auch auf diese Art, eine erhebliche Fettmästung zu erzielen; auf der Höhe der Mästung und mitten im Zustand der Ueberfütterung wurde das Thier geschlachtet: es zeigte ein ganz normales Blut mit klarem Serum. Der Gehalt des Blutes an Fett (Aetherextract) betrug $0,35 \%$. Ich glaube daher nicht fehlzugehen, wenn ich annehme, das Fett des milchartigen Serums stamme aus dem Fett der Nahrung. Man hat zu berücksichtigen, dass Roggenmehl nicht gerade arm an Fett ist, nämlich von demselben $1^{1 / 2}$ bis $2^{1 / 2} \%$ enthalten kann. Bei der Ueberfütterung mit grossen Mengen Roggenmehl wird also auch stets eine ziemlich grosse Menge Fett mitgefüttert, welches, in das Blut resorbirt, bei der schon vorhandenen grossen Ueberladung der Gewebe mit. Fett in diesen zunächst keine Aufnahme finden kann.

Ausser den Versuchen, welche dazu dienten, das Verhalten des respiratorischen Quotienten während möglichst starker Fettbildung kennen zu lernen, wurden zwei andere Respirationsversuche im Hungerzustande ausgeführt, einer bei Thier Nr. I, nachdem das Thier ungefähr 7 Wochen gemästet und dann eine Reihe von Hungertagen eingeschoben war, ein zweiter bei Thier Nr. II, ohne vorherige Mästung. Dieselben geben einen Anbaltspunkt über die Stoffwecbselgrösse der Gänse im Hungerzustand; hauptsächlich wurden sie aber zum Zwecke der Controle des Respirationsapparates unternommen, wie unten näher ausgeführt werden wird. 


\section{Der Respirationsapparat.}

Da es sich bei den beabsichtigten Versuchen darum handelte, sowohl die von den Thieren in einer gewissen Zeit producirte Kohlensäure als auch den verbrauchten Sauerstoff direct zu messen, so wurde ein nach dem Regnault'schen Princip construirter Respirationsapparat in Anwendung gebracht. Der zuverlässigste Apparat dieser Art ist der von P fl ü ger construirte, welcher zuerst. bei den im hiesigen physiologischen Institut ausgeführten Respirationsversuchen von Colasanti und Finkler benutzt wurde. (Ausfübrliche Beschreibung dieses Apparates s. in Colasanti's Arbeit „Ueber den Einfluss der umgebenden Temperatur auf den Stoffwechsel der Warmblüter", dieses Archiv Bd. 14 S. 94, sowie Finkler "Beiträge zur Lehre von der Anpassung der Wärmeproduction an den Wärmeverlust bei Warmblütern", dieses Archiv d. 15 S. 603).

Das Wesentliche an diesem Apparat ist, dass die Luft des nach allen Seiten vollk ommen dicht verschlossenen Respirationsraumes durch eine Sauge- und Druckvorrichtung in bestimmter Richtung in Cireulation versetzt und dureh Kalilauge hindurch getrieben wird, und dass ferner zur sicheren Gewäbrleistung der Dichtigkeit des Apparates alle Gummischläuche und Gummiverbindungen in Wasser versenkt $\sin d$.

Der Hauptsache nach war der von mir angewandte Apparat, (s. Taf. III) nach dem Vorbilde dieses früher benutzten eingerichtet; als Sauge- und Druckvorrichtung diente dasselbe Quecksilbergebläse $q$, welches von $\mathrm{Finkler}$ und $\mathrm{Col}$ as anti angewandt worden war. Die spritzflaschenähnlichen Kaliventile I, II, III, IV wurden entsprechend der gröfseren Kohlensäuremengen, die sie bewältigen sollten, etwas grösser genommen. Die Sauerstoffzuleitung erfolgte genau nach dem von Finkler a. a. $\mathrm{O}$. beschriebenen Princip. Anders musste aber für das viel grössere Thier (Finkler und Colasanti benutzten den Apparat für Versuche an Meerschweinchen) der Thierrecipient gestaltet sein. Derselbe war ein aus starkem Kupferblech verfertigter Behälter $r$, der in seiner Form sich schon einigermaassen der Gestalt des zu benutzenden Thieres, der Gans, anpasste. Derselbe bestand aus zwei Stücken, einem unteren und einem oberen. Das untere Stück hatte die Form einer Wanne; wenn das Thier in dieselbe hineingesetzt wurde, so fülte es den Raum der Wanne nicht 
aus, sondern es blieb nach allen Seiten noch reichlich Platz übrig; der Hals und der Kopf des Thieres ragten aus der Wanne hervor. Der obere Rand des Kupferbeckens war ringsum nach aussen wagerecht umgebogen und zum Zweck der Dichtung mit einem Gummistreifen belegt. Der obere Theil des Thierrecipienten war ein ebenfalls aus Kupfer getriebener Deckel, der auf die Wanne aufgelegt und mit 16 Flügelschrauben fest an dieselbe angepresst werden konnte. Für Hals und Kopf des Thieres befand sich auf dem vorderen Theile dieses Deckels ein kastenförmiger Kopfaufsatz, der seitlich mit zwei fest eingekitteten Glasfenstern $f$ versehen war, so dass man von dem im Apparat sitzenden Thiere stets den Kopf und Hals beobachten konnte. Wenn auch durch die 16 Schrauben und die Gummidichtung die beiden Stücke des Thierrecipienten so fest an einander geschlossen waren, dass der Apparat an der Grenzstelle wohl als dicht anzusehen war, so war es doch wünschenswerth, dieser Stelle hinsichtlich der Dichtigkeit noch eine grössere Sicherheit zu geben. Desshalb wurde auch dieser Theil in Wasser versenkt und zwar dadurch, dass an dem oberen Rande der Wanne eine rundum laufende kragenförmige Rinne $k$ aus dünnem Kupferblech angebracht wurde, die einige Centimeter über die Höhhe der Fuge zwischen den beiden Theilen des Recipienten emporragte. Sobald das Thier in den Recipienten eingesetzt und die Schrauben angezogen waren, was unter Assistenz mehrerer Gehülfen nur wenig Zeit erforderte, wurde die Rinne voll Wasser gegossen, wodurch der grösste Theil des Deckels und besonders die ganze Fuge unter Wasser zu liegen kam. In den Thierrecipienten, und zwar grösstenteils in den Kopfaufsatz, mündeten eine Anzahl von Metallröhren, welche theils der Ventilation, theils der Sauerstoffzuleitung, sowie der Anbringung eines Thermometers und eines Manometers dienten. Das Thermometer $t$ wurde mittelst eines durchbohrten, sehr gut schliessenden Gummistopfens durch das zugehörige Rohr in den Kopfaufsatz des Recipienten eingelassen; die Kugel des Thermometers war mit einer Schutzvorrichtung umgeben, so dass dieselbe von dem Kopf des Thieres nicht unmittelbar berührt werden konnte. Das Manometer $m$ war ebenso eingerichtet wie bei dem Apparat von Cojasanti, d. h. das entsprechende Metallrohr. war senkrecht nach abwärts gebogen und mit einem Glasrohr verbunden, welches mit seinem unteren Ende in ein cylindrisches Gefäss mit concentrirter Chlorcalciumlösung eintauchte. An dem Stand der. Flüssigkeit in diesem Glasrohr liess sich erkennen, ob, wie beabsich- 
tigt, der Druck im Apparat dem Atmosphärendruck gleich blieb. In Folge des Ganges der Ventilationsvorrichtung schwankte der Druck im Apparat gleichmässig um den atmosphärischen Druck als Mittel, ohne dass die Schwankungen eine grössere Abweichung vom atmosphärischen Druck als etwa 1 bis $1^{1 / 2}$ mm Quecksilber erreichten.

Vier Metallröhren dienten der Ventilation; mit ihrem peripheren Ende waren sie alle so nach unten gebogen, dass sie in das grosse Wasserreservoix w eintauchten, wo sie erst durch Gummischläuche mit den Kaliventilen I, II, III, IV in Verbindung gesetzt waren. Im Thierrecipienten mündeten von diesen Metallröhren drei in den Kopfaufsatz, theils oben in demselben endigend, theils tiefer in denselben hineingeführt; das vierte Rohr war, um eine möglichst ausgiebige Ventilation des Recipienten zu ermöglichen, nach dem hinteren Theile desselben, etwa in die Schwanzgegend des Thieres, hingeleitet, indem es hier den Kupferdeckel durchsetzte und noch einige Centimeter tief in den Innenraum des Apparates eindrang. Man sieht demnach, dass die Ventilationsröhren so vertheilt waren, dass das ganze Thier von dem Stron der bewegten Luft umspült wurde. Die Einrichtung des Ventilationsapparates und der vier der Kohlensäure-Absorption dienenden Kaliventile ist aus der Zeichnung (Taf. III) ersichtlich. Man sieht, dass bei der getroffenen Anordnung die vier Metallröhren immer nur in der von den Pfeilen angedeuteten Richtung von der Luft durchströmt werden. Die ausgezogenen Pfeile bedeuten in der Zeichnung die eine, die gestrichelten Pfeile die andere Phase im Gange des Quecksilbergebläses. Die aus dem Recipienten angesaugte Luft muss zwei Mal durch Kalilange hindurch gehen, ehe sie wieder in den Recipienten eintritt. Aehnlich wie bei Colasanti und Finkler waren auch hier in die Gummischläuche, welche von den Metallröhren zu den Kaliventilen führten, Glaskugeln eingeschaltet, welche zur Entnabme von Luftproben dienten. Ich hatte die Einrichtung so getroffen, dass nur am Schluss des Versuches solche Luftproben entnommen wurden, um festzustellen, welche Zusammensetzung die Luft des Thierrecipienten am Ende des Versuches hatte. (Bei Colasanti war die Einrichtung so, dass auch während des Versuches Proben entnommen werden konnten.) Die Kugeln waren daher in die beiden Verbindungen eingeschaltet, welche Luft von dem Thierrecipienten abführten, also in diejenigen, welche zu den Ventilen I und III hinführten. Man sieht aus der Zeichnung, dass die Kugel $h$ von Luft durchströmt wurde, die vom hinteren Theile, 
die Kugel $v$ von solcher, die aus dem Kopfaufsatz des Apparates herausströmte; so wurden Luftproben aus zwei entgegengesetzten Theilen des Apparates erhalten. Die Probekugeln waren in gut schliessenden Glasschliffen aufgehängt und konnten an ihrem einen Ende mit eingeschliffenem Stöpsel verschlossen werden. Im Moment der Beendigung des Versuches wurden die Gummischläuche zu beiden Seiten der Kugeln durch Klemmen fest verschlossen, alsdann zuerst das mit Stöpsel verschliessbare Ende in Quecksilber eingetaucht, unter Quecksilber die Kugel aus ibrer Glasschliffverbindung mit dem Rohr herausgenommen und, ebenfalls unter Quecksilber, der gutschliessende Glasstopfen aufgesetzt, dann das andere Ende in einen Quecksilbernapf eingetaucht und so endlich die Probekugel mit dem Quecksilbernapf aus dem Wasserbehälter herausgehoben und die Luftproben direct in die Röhren für die gasometrischen Analysen umgefüJlt.

Die Sauerstoffzuleitung geschah ganz nach dem von Finkler in seiner Arbeit (dieses Arch. Bd. 15, S. 605) angegebenen Princip, welch es darin besteht, dass immer eine so grosse Menge von Sauerstoff selbstthätig in den Thierrecipienten eindringen muss, als nöthig ist, um den durch den Sauerstoffverbrauch des Thieres gesunkenen atmosphärischen Druck im Recipienten wiederherzustellen. Unter der Voraussetzung, dass das Thier während des Versuches von Gasen nur Sauerstoff verbraucht und nur Kohlensäure producirt, die sämmtliche Kohlensäure aber durch die Kaliventile absorbirt wird, wird ja die im Thierrecipienten (einschliesslich der Ventilationseinrichtung) eingeschlossene Gasmenge um die Menge des verbrauchten Sauerstoffs verringert und der Luftdruck im Apparat entsprechend herabgesetzt. Wenn nun der Thierrecipient mit einem Sauerstoffbehälter verbunden ist, in welchem durch eine besondere Vorrichtung der Druck stets dem atmosphärischen gleich gehalten wird, so muss aus dem Sauerstoffbehälter stets genau so viel Sauerstoff in den Thierrecipienten hineinfliessen, als von dem Thier verbraucht worden ist. Um dem Leser das Nachlesen der Beschreibung des Finklerschen Apparates zu ersparen, füge ich hier (Fig. 1) die Abbildung desselben bei (dieses Arch. Bd. 15 S. 606).

In den oberen Theil des Sauerstoffbehälters 0 mündet ein schräg von unten nach oben gehendes Robr $a$, an dessen freies Ende ein U-förmig herunterhängender Gummischlauch $b$ angesteckt ist; in das aufsteigende Ende dieses Gummischlauches ist ein kurzes Trichterrohr $c$ eingebunden. Rohr, Gummischlauch und Trichtergefäss sind 
mit concentrirter Chlorcalciumlösung gefüllt, und zwar so, dass das schräge Glasrohr a gerade bis zu seiner Einmündungsstelle in den Sauerstoffrecipienten gefüllt ist. Beim Beginn des Versuches wird nun so eingestellt, dass im Sauerstoffrecipienten genau atmosphärischer Druck herrscht, also die Flüssigkeit in $c$ genau in derselben Höhe steht wie die Einmündungsstelle von $a$ in $o$. Bei jeder Druckverminderung im Recipienten läuft die Flüssigkeit sofort aus dem Ende des Mündungsrohres a über, an der Wand des Sauerstoff-

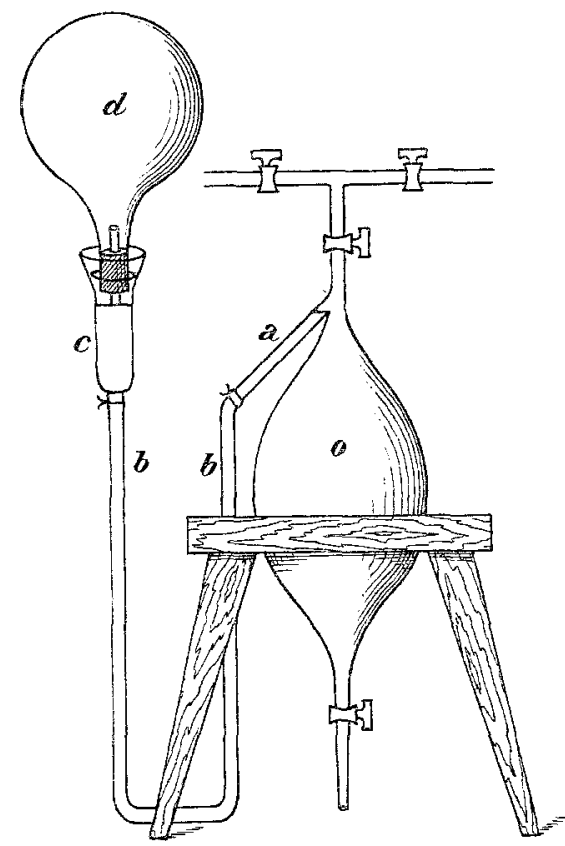

Fig. 1. behälters $o$ herab bis auf dessen Boden. Durch diesen Abfluss sinkt das Niveau im Trichterrohr $c$, wird aber wieder zur früberen Höhe gebracht vermittelst der schon von Reg$\mathrm{n}$ ault angewandten umgestülpten Flaschen $d$, deren Oeffnung in das ursprüngliche Flüssigkeitsniveau des Trichters eintauchte. So regulirt sich der Apparat selbst in der Art, dass der Sauerstoff im Recipienten stets unter Atmosphärendruck bleibt. Der von dem Thier verbrauchte Sauerstoff wird also - wenn gewisse, unten noch zu besprechende Voraussetzungen erfüllt sind - genau durch die Menge der aus der Flasche d auslaufenden Chlorcalciumlösung gemessen. In einigen Versuchen habe ich einen Apparat benutzt, der ganz dem oben beschriebenen entsprach. Weil indess meine Thiere ein viel grösseres Sauerstoffquantum verbrauchten, als es bei den Versuchen Finkler's in Betracht kam, so war ich genöthigt, den Sauerstoffrecipienten $o$ viel grösser zu nehmen. Da aber für diese Grösse die birnförmige Gestalt nicht mehr zweckmässig war, so änderte ich den Apparat in folgender Art ab, ohne das Princip zu ändern : als Sauerstoffbehälter diente eine grosse, etwa $8^{1 / 2}$ Liter fassende Mits ch e r li ch' sche Glasflasche $o$ (Fig. 2). In den einen oberen Tubus derselben war ein kurzes weites Glasrohr luftdicht eingesetzt, welches nach oben in einer Glaskugel $g$ 
auslief, in welche das schräge Glasrohr $a$ einmündete, während der andere obere Tubus das nach dem Thierrecipienten hinführende Rohr enthielt.

Da als Gas messende Flaschen $(d)$ Einliterflaschen dienten, das Thier aber während eines Versuches bis zu 7 Liter Sauerstoff verbrauchte, so war ferner noch, damit das Einwechseln der neuen Flaschen keine Unterbrechung im Verlauf des Versuches bedinge, das U-förmige Gummirohr gegabelt und entsprechend das trichterförmige Rohr $c$ doppelt vorhanden, aber immer nur eins in Thätigkeit, während der Gummischlauch zu dem anderen abgeklemmt blieb,

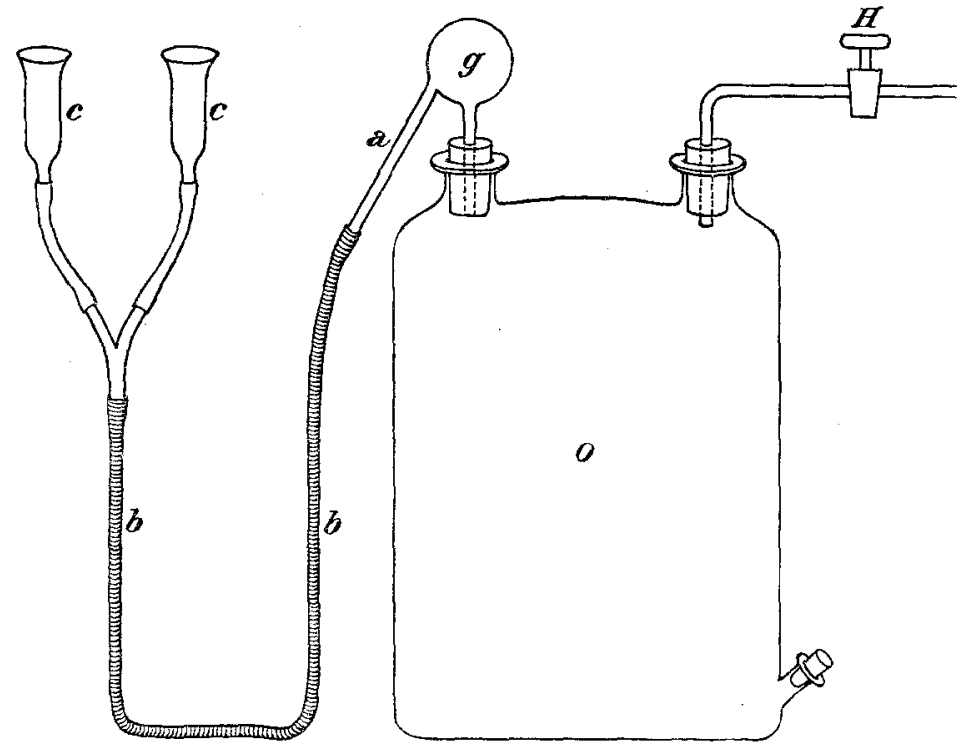

Fig. 2.

so dass hier eine neue Flasche (d) aufgenommen werden konnte, während die andere verbraucht wurde. (In der Tafel III ist der Einfachheit halber $e$ nur ein Mal gezeichnet.)

An der Einmündungsstelle des Sauerstoff zuführenden Rohres in den Thierrecipienten (Taf. III) war, ebenso wie in den Versuchen von Finkler und Colasanti, ein kleines, mit Chlorcalciumlösung gefülltes Ventil $G$ angebracht, welches nur einen Eintritt, nicht aber einen Austritt von Gas aus dem Thierrecipienten gestattete.

Wo auf dem Wege vom Sauerstoffbehälter zum Thierrecipienten Glashähne angebracht waren, waren dieselben mit sehr weiter Bohrung versehen, um dem Gasstrome einen möglichst ungehinderten Weg zu gestatten. 
Eine "Maassnahme muss ich noch besprechen, welche sich bei den Versuchen mit dem relativ grossen Versuchsthier als nothwendig erwies. Die Annahme, dass bei der getroffenen Versuchsanordnung die in den Thierrecipienten nachdringende Gasmenge gleichzeitig das Maass des verbrauchten Sauerstoffs sei, beruht auf der Voraussetzung, 1. dass das Thier anderes Gas als Sauerstoff nicht verbraucht, 2. dass das Thier anderes Gas als Koblensäure nicht producirt, 3. dass alle producirte Kohlensäure in den Kaliventilen vollständig absorbirt wird, 4. dass der atmosphärische Luftdruck während des Versuches sich nicht ändert, 5. dass die Temperatur im Thierrecipienten während des Versuches unverändertbleibt.

Die ersten Vorversuche mit der Gans zeigten, dass bei dem beschriebenen Respirationsapparat besonders die letzte Bedingung nicht erfüllt war. Der grosse Thierkörper erwärmte die verhältnissmässig kleine Luftmenge des Respirationsraumes so stark, dass die zuströmende Sauerstoffmenge bei Weitem nicht ausreichte, um den verbrauchten Sauerstoff zu ersetzen. Desshalb sank der Sauerstoffgehalt der Luft im Apparat in kurzer Zeit unter das Maass dessen, was das Thier zum Athmen nöthig hatte, so dass das Thier zu ersticken begann und der Versuch schleunigst unterbrochen werden musste. Desshalb war eine Vorkehrung nöthig, um das starke Ansteigen der Temperatur im Apparat während des Versuches zu verhindern. Dieses erreichte ich folgendermaassen: Ich setzte das Thier nicht direct in den Thierrecipienten, sondern in eine kleine Wanne aus Zinkblech $z$, in die das Thier in sitzender Stellung gerade hineinpasste. Dann füllte ich das Kupferbecken selbst mit Wasser an, so dass der Spiegel desselben nur noch wenige Centimeter unter dem Rande der kleineren Wanne stand; die Wanne war mit Gewichten beschwert, um den Auftrieb zu verhindern. Die zur Ausfüllung des Kupferbeckens erforderliche Wassermenge betrug 10 bis 12 Liter und erwies sich als hinreichend, um die Erwärmung der Luft des Respirationsraumes auf ein geringes Maass herunterzudrücken oder auch dieselbe ganz zu verhindern. Die noch bleibende Temperaturdifferenz wurde bei der Berechnung der Sauerstoffverbrauchs in Rücksicht gezogen.

Auch die oben unter 3. genannte Bedingung liess sich bei der gegebenen Grösse der Ventilationsvorrichtung nicht ganz erfüllen. Es müsste ja, wenn alle producirte Kohlensäure in den Kaliventilen absorbirt werden sollte, die Ventilation eine so vollkommene sein, 
dass in der Luft des Thierrecipienten am Schlusse des Versuches nicht mebr Kohlensäure enthalten ist als in der atmosphärischen Luft. Am Schlusse der Versuche enthielt die Luft des Apparates immer eine gewisse Menge Kohlensäure, besonders bei den während der Mästungszeit angestellten Versuchen, wo die Kohlensäureproduction der Thiere bis auf 10 Liter in der Stunde stieg und daher die Anforderungen an die Koblensäure absorbirende Vorrichtung sehr gross waren. Der in Folge dessen am Schlusse des Versuches dureh die Analysen der Luftproben festgestellte Kohlensäuregehalt der Luft im Apparat war der in den Kaliventilen absorbirten Kohlensäure zuzurechnen (ausser der geringen Menge, welche als normaler Kohlensäuregehalt der atmosphärischen Luft schon vorher vorhanden war). Natürlich ist aber dieselbe Volumgrösse auch dem Sauerstoffverbrauch des Thieres zuzurechnen, da für jeden Raumtheil Kohlensäure, der sich während des Versuches in der Luft des Apparates ansammelt, ein gleicher Raumtheil Sauerstoff in den Apparat nachzudringen verhindert wird. Hinsichtlich der Berechnung der Kohlensâuremenge, welche sich am Schlusse des Versuches im Thierrecipienten befindet, ist zu beachten, dass der durch die Analyse der Luftproben gefundene Kohlensäuregehalt nur für die Luft des Thierrecipienten selbst (und einen Theil der Ventilationsvorrichtung) gültig ist. Jenseits der Ventile I bis IV ist die Luft schon ein Mal durch Kalilauge hindurchgegangen und hat daher nicht mehr diesen Kohlensäuregehalt. Nun fand ich, dass in den Ventilen II und IV, welche die Luft auf ihrem Rückwege von den Quecksilberaspiratoren zum Thierrecipienten passirt, auch noch Kohlensäure absorbirt wurde. Also war das einmalige Durchgehen durch Kalilauge noch nicht genügend, um alle Kohlensäure $\mathrm{zu}$ absorbiren. Es enthält daher auch die Luft jenseits der Ventile noch etwas Kohlensäure. Die Luftmenge des Raumes, auf den es hier ankommt, betrug in den meisten Versuchen ca. $2000 \mathrm{ccm}$, während der Raum des Thierrecipienten in den verschiedenen Versuchen zwischen 16000 und $20000 \mathrm{ctm}$ betrug. Wir haben also in dem geschlossenen Raum eine grosse Luftmenge mit höherem Kohlensäuregehalt und eine viel kleinere mit niedrigerem Kohlensäuregehalt. Da von der Luft in dem kleineren Raum keine besondere Analyse gemacht wurde, so habe ich ihren Kohlensäuregehalt durch Schätzung ermittelt: Der Gehalt ist kleiner als im grossen Raum und grösser als Null; ich habe daher das Mittel angenommen. Ein grosser Fehler wird da- 
durch offenbar nicht begangen, da der in Betracht kommende Raum nur etwa ${ }^{1 / 10}$ des grossen Raumes beträgt ${ }^{\mathbf{1}}$ ).

Was die unter 2. genannte Bedingung betrifft, so wäre für in dem Respirationsraum während des Versuches sich ansammelndes Sumpfgas und Wasserstoff ebenfalls eine entsprechende Correctur aln verbrauchten Sauerstoff anzubringen. Es stellte sich aber das bemerkenswerthe Resultat heraus, dass, trotzdem die Thiere sich bei den Mästungsversuchen stets auf dem Höhepunkt der Verdauungsthätigkeit befanden, doch in den Luftproben weder Methan noch Wasserstoff nachzuweisen war.

Eine Correctur wegen Schwankungen des Barometerstandes während des Versuches erwies sich als unnöthig, weil bei der kurzen Dauer der Versuche (bis 1 Stunde) der zu Anfang und zu Ende abgelesene Barometerstand keine in Betracht kommenden Schwankungen zeigte.

Man sieht, dass in unserem Apparat (und dasselbe gilt überhaupt von den nach Regnault'schem Princip eingerichteten Apparaten) die von dem Thier producirte Kohlensäure sich aus zwei Theilen zusammensetzt:

1. aus der in den Kaliventilen absorbirten Kohlensäure,

2. aus der in dem Respirationsraume verbliebenen (der Absorption durch die Kaliventile entgangenen) Kohlensäure,

während der von dem Thier verbrauchte Sauerstoff sich aus drei Theilen zusammensetzt, nämlich

1. aus der Gasmenge, die aus dem Sauerstoffrecipienten in den Thierrecipienten eingedrungen ist, gemessen durch die aus der Sauerstoff messenden Flasche $d$ ausgeflossene Flüssigkeit;

2. aus derjenigen, welche aus dem Sauerstoffbehälter mehr zugeströmt sein würde, wenn nicht im Apparat sich eine gewisse Menge Kohlensäure (und eventuell auch brennbares Gas, falls solches gebildet worden) angesammelt hätte;

3. Aus derjenigen Menge, welche mehr zugeströmt sein würde, wenn sich der Luftraum des Apparates nicht um einen gewissen Temperaturbetrag erwärmt hätte (dieser Betrag ist natürlich negativ, falls eine Abkühlung während des Versuches stattgefunden hat).

Der Respirationsapparat ist natürlich um so vollkommener, je

1) Die Rohrverbindungen der Ventile II und IV mit dem Thierrecipienten sind mit Luft gefüllt, die zwei Mal durch Kalilange gegangen ist; da es sich aber hier um eine nur ganz kleine Raummenge handelt, so habe ich von einer besonderen Berücksichtigung dieses Umstandes abgesehen. 
vollständiger sowohl die Kohlensäure als der Sauerstoff von den unter 1. genannten Beträgen gemessen werden.

Bei meinen Versuchen, bei denen ich genöthigt war, die Apparate mit möglichst sparsamen Mitteln einzurichten, konnte bei äusserster Inanspruchnahme der Ventilationseinrichtung den zu stellenden Anforderungen noch gerade genügt werden. Ohne Zweifel wäre eine Vergrösserung der Ventilationseinrichtung wünschenswerth gewesen; aber dieselbe hätte den Apparat sehr vertheuert, besonders wegen der in dem Trommelgebläse erforderlichen grösseren Menge Quecksilber. Ein Ersatz des Quecksilbers durch concentrirte Chlorcalcium-Lösung würde hier vielleicht zweckmässig sein.

Von den am Schlusse des Versuches entnommenen Luftproben wurde jedes Mal nicht bloss der Gehalt an Kohlensäure und brennbaren Gasen, sondern auch der Sauerstoffgehalt bestimmt. Diese Bestimmung gestattet eine sehr werthvolle Controle für die Richtigkeit der ermittelten Zahlen für den Sauerstoffverbrauch. Es liegt nämlich auf der Hand, dass man, wenn die Grösse des Luftraumes im Apparat bekannt ist, aus der Menge des dem Apparate zugeströmten Sauerstoffs und der Menge des vom Thier verbrauchten Sauerstcifs den Sauerstoffgehalt, welchen die Luft im Apparat am Schlusse des Versuchs haben muss, berechnen und die berechnete Zahl mit der durch Analyse gefundenen vergleichen kann. Zum Zwecke dieser Berechnung muss man aber noch die Zusammensetzung des im Sauerstoffrecipienten enthaltenen Gases kennen. Der Sauerstoff wurde aus chemisch reinem chlorsaurem Kali dargestellt, enthielt aber durch Verunreinigung mit atmosphärischer Luft stets etwas Stickstoff ${ }^{1}$ ). Jedes Mal unmittelbar vor und unmittelbar nach dem Versuch wurde aus dem Sauerstoffbehälter eine Probe entnommen und der Sauerstoffgehalt darin bestimmt. Die Verunreinigung

1) Diese Verunreinigung mit Stickstoff ist ja für den Versuch an und für sich ohne Belang. Ein möglichst sauerstoffreiches Gasgemenge als Ersatz für den verbrauchten Sauerstoff zuzuführen, ist nur insofern von Bedentung, damit nicht die Sauerstoffspannung der von dem Thier, zu athmenden Luft unter das zulässige Maass sinke. Im dritten der unten mitgetheilten Versuche, wo das zugeführte Sauerstoffgas nur 88,57\% Sauerstoff enthielt, sank daher der Sauerstoffgehalt der Luft im Apparat am Schlusse des Versuches bis 14,22\%. Das war vielleicht schon eine etwas zu starke Verarmung der vom Thier zu athmenden Luft an Sauerstoff. Indessen möchte ich hervorheben, dass weder in diesem noch in irgend einem anderen der mitgetheilten Versuche das Thier irgend welche Zeichen von Dyspnoë darbot; im Gegentheil, die Thiere machten ganz den Eindruck, als wenn sie sich in dem Apparat recht behaglich fühlten. 
mit Stickstoff muss natürlich in Rechnung gezogen werden, wenn man wissen will, wie viel reiner Sauerstoff in den Thierrecipienten eingeströmt ist.

Ausserdem ist noch zu berücksichtigen, dass der Raum zwischen dem Hahn $H$ und dem Thierrecipienten am Anfang des Versuches nicht mit Sauerstoff, sondern atmosphärischer Luft gefüllt war; im ersten Moment des Versuches tritt daher eine gewisse Gasmenge ein, welche statt der Zusammensetzung des Sauerstoffgases im Sauerstoffrecipienten die Zusammensetzung der atmosphärischen Luft hat. Auch dafür ist ein entsprechender Abzug an dem in den Thierrecipienten eindringenden Sauerstoff anzubringen. Die reine Sauerstoffmenge, welche während des Versuches in den Thierbehälter eingedrungen ist, ist demnach gleich der direct durch die Sauerstoff messenden Flaschen $d$ berechneten Menge, vermindert um denjenigen Theil dieser Gasmenge, welcher nach der Analyse des Gases im Sauerstoffbehälter nicht Sauerstoff ist, und um denjenigen Theil des Gases im erwähnten "schädlichen Raum", der nicht Sauerstoff ist (d. h. c. $79 \%$ desselben).

Der Vergleich der in den einzelnen Versuchen für den Sauerstoffgehalt am Schlusse des Versuches berechneten und gefundenen Werthe zeigt durchweg eine sehr befriedigende Uebereinstimmung. Eine vollständige Uebereinstimmung ist desshalb nicht zu erwarten, weil die Ermittlung des Sauerstoffgehaltes am Schlusse des Versuches aus den Analysen der beiden Luftproben nur dann eine ganz genaue wäre, wenn die Luft als vollkommen gemischt gelten dürfte; nun schöpft die Kugel $v$ ihren Inhalt aus dem vorderen, die Kugel $h$ aus dem hinteren Theile des Apparates. In dem vorderen Theile besonders begegnen sich die Ventilationsströme der von Kohlensäure gereinigten Luft mit dem Strome der von dem Thiere ausgehauchten Luft und dem eindringenden Sauerstoff. Desshalb zeigen schon die beiden Luftproben aus $v$ und $h$ unter einander geringe Abweichungen, und auch das Mittel aus beiden wird die Zusammensetzung der vollständig gemischt gedachten Luft des Apparates nur mit einer gewissen Annäherung angeben.

Eine andere Controle für die Zuverlässigkeit des Apparates liegt in den beiden unten beschriebenen Versuchen mit hungernden Thieren. Da hier der zu erwartende Werth für den respiratorischen Quotienten bekannt ist bezw. nur in engen Grenzen schwankt, so darf es als Probe für den Apparat angesehen werden, wenm diese Werthe wirklich gefunden werden. 


\section{Die Gasanalvsen.}

Die in den vier Ventilen absorbirte Kohlensäure wurde nach Pflüger's Methode durch Auspumpen mit Phosphorsäure in der Quecksilberluftpumpe gasanalytisch bestimmt. Zu diesem Zwecke wurde der Inhalt der vier Ventile nach dem Versuche in einen grossen (2 L. -) Maasskolben hinübergespült, die Maassflasche bis zur Marke aufgefüllt und nach sorgfältigem Mischen ein aliquoter Theil in den Recipienten der Luftpumpe hineingemessen. Da es schwierig ist, ein reines Kalihydrat zu erhalten, dasselbe vielmebr schon immer eine mehr oder weniger beträchtliche Menge Kohlensäure enthält, so besteht die aus dem Inhalt der vier Ventile ausgepumpte Kohlensäure stets zum Theil aus solcher Kohlensäure, welche schon vor dem Versuch in der Lauge enthalten war. Die Menge dieser präformirten Kohlensäure wurde durch eine besondere Analyse bestimmt und von der Gesamtmenge der gefundenen Kohlensäure in Abzug gebracht. Dabei wurde so verfahren, dass eine gewisse Menge der Lauge mit demselben destillirten Wasser in demselben Verhältniss verdünnt wurde wie der Inhalt der vier Ventile, um so auch die im destillirten Wasser enthaltene geringe Kohlensäuremenge wieder in Abzug zu bringen.

Da das im Thierrecipienten befindliche destillirte Wasser ebenfalls etwas von der gebildeten Kohlensäure absorbiren wird, bezw. wenn das destillirte Wasser sehr kohlensäurereich ist, auch Kohlensäure an die Luft des Respirationsapparates abgeben könnte, so wurde in einem Versuche auch der Gehalt dieses Wassers an Kohlensäure vor und nach dem Versuche bestimmt, wobei sich indessen herausstellte, dass die in Betracht kommende Kohlensäuremenge so gering war, dass sie ohne grösseren Fehler vernachlässigt werden kann.

Die Analyse der aus den Glaskugeln erhaltenen Luftproben erfolgte nach den Bunsen'schen Methoden, die Bestimmung der Kohlensäure in diesen Luftproben durch Einbringen von sehr verdünnter Kalilauge vom spec. Gew. 1,030 in das Eudiometer. Für diese Kalilauge darf nach $P$ fl üg e $\mathrm{r}^{1}$ ) dieselbe Tension wie für das Wasser angenommen werden, was für die Analyse sehr bequem ist. Auch die Analysen des benutzten Sauerstoffgases wurden nach Bunsen'scher Vorschrift ausgeführt.

1) Dieses Archiv Bd. 14 S. 108.

E. Pflüger, Archiv für Physiologie. Bd. 85 . 


\title{
Versuchsprotokolle.
}

\author{
1. Versuch. 11. November 1893.
}

Thier Nr. I. Gewicht 4780 g. Fütterung des Thieres um 91/2 Uhr Morgens und am 21/2 Nachm. 1/2. Stunden nach dieser Fütterung wurde der Versuch begonnen.

In den Kaliventilen $120 \mathrm{~cm}$ conc. Kalilauge.

Anfang des Versuches $4^{\mathrm{h}}$ 3' $^{\prime}$

Ende $\left.4^{\mathrm{h}} 35,\right\}$

Daner des Versuches 32 Minuten.

Barometer (auf $0^{\circ}$ reduc.) 764,2 mm.

Temperatur im Versuchszimmer $9,1^{\circ}$ (am Sauerstoffbehälter gemessen).

Temperatur im Thierrecipienten (Thermometer im Kopfaufsatz des Apparates)

am Anfang des Versuches $10,0^{\circ}$ Temperaturzunahme während des

\#Ende $\left.\# \quad 12,6^{\circ}\right\} \quad$ Versuches $2,6^{\circ}$

Sauerstoffverbrauch, nach dem Volum der aus den "Sauerstoffmessenden Flaschen" ausgelaufenen Chlorcalciumlösung gemessen

(auf $0^{\circ}$ und $760 \mathrm{~mm}$ Druck reducirt) $2999,2 \mathrm{ccm}$.

Kohlensäure-Erzeugung: Der Inhalt der vier Ventile auf $2000 \mathrm{ccm}$ gebracht. Davon zwei Proben zur $\mathrm{CO}_{2}$-Bestimmung verwandt.

1. Analyse. $20 \mathrm{ccm}$ dieser verdünnten Lauge enthalten $50,121 \mathrm{ccm} \mathrm{CO}_{2}$ $2000 \mathrm{ccm}$ demnach $=5012,1 \mathrm{ccm}$ Kohlensäure $\left(0^{\circ}, 760 \mathrm{~mm}\right)$

2. Analyse. $50 \mathrm{~cm}$ der verdünnten Lauge enthalten $125,46 \mathrm{ccm} \mathrm{CO}_{2}$ $2000 \mathrm{ccm}$ demnach $=5018,4 \mathrm{ccm}$ Kohlensäure.

Kohlensäuregehalt der vier Ventile im Mittel. . $5015,2 \mathrm{ccm}$ Kohlensäure.

Je $1 \mathrm{ccm}$ der benutzten $120 \mathrm{ccm}$ conc. Kalilauge enthält nach besonderer Analyse $3,956 \mathrm{ccm} \mathrm{CO}_{2}$. Also präformirte Kohlensäure. . . . . . . . . . $474,7 \mathrm{ccm}$ Kohlensäure.

Also von dem Thier gebildet . . . . . . $\frac{474,7540,5 \mathrm{~cm}\left(0^{0}, 760 \mathrm{~mm}\right)}{4}$

Analysen der Luftproben. In die Kugel $h$ war aus dem Ventil $\mathrm{I}$ eine Spur Kalilauge hinübergespritzt. Die Luftprobe erwies sich in Folge dessen als kohlensäurefrei. Zur Luftanalyse wurde daher nur der Inhalt von $v$ benutzt. Breunbare Gase konnten nicht nachgewiesen werden. Im Uebrigen enthielt das Gas Kohlensäure $1,9 \%$, Sauerstoff $17,52 \%$.

Die Analyse des Gases im Sauerstoffbehälter ergab $94,65 \%$ Sauerstoff. In der Kupferwanne des Thierrecipienten befanden sich $10 \mathrm{l}$ destillirtes Wasser. Der g e sammte L u f t in halt des Thierrecipienten ${ }^{1}$ ) sammt Ventilationsvorrichtung beträgt 21,5 Liter, wovon 2 Liter auf den Raum jenseits der Kaliventile kommen. Der gesammte Luftinhalt des Apparates, auf $0^{\circ}$ und $760 \mathrm{~mm}$ Druck reducirt, beträgt zu Anfang des Versuches 20,856 Liter,

zu Ende des Versuches 20,666 Liter.

1) Für das Volum des Thieres wurden stets ebenso viele Kubikcentimeter in Abrechnung gebracht, als das Thier Gramm wog. 
Für den Sauerstoffyerbrauch kommt in Betracht:

1) Die direct gemessene Menge. . . . . . . . . . . 2999,2 ccm

2) Correctur für Temperaturerhöhung . . . . . . . . . . 190,0 ccm

3) Correctur für Kohlensäure im Apparat

a) für den grossen Raum 18,746 Liter mit $1,9 \% \mathrm{CO}_{2}=356,2 \mathrm{ccm}$

b) für den kleinen Raum 1,920 Liter mit $0,95 \% \mathrm{CO}_{2}=18,2 \mathrm{ccm}$

zusammen $\overline{374,4 \mathrm{ccm}}$

Abzug für $\mathrm{CO}_{2}$ der atm. Luft am Anfang des Versuchs 8,1 ,

bleiben . . $\quad 366,3 \mathrm{ccm}$

Gesammtverbrauch an Sauerstoff .. . . . . . . . . $\overline{3555,5 \mathrm{ccm}}$

Für die Menge des zug es trömten Sa uerstoffs erhält man obige $2999,2 \mathrm{ccm}$.

Davon ist aber abzuziehen:

1) diejenige Menge dieses Gases, die nicht Sauerstoff war,

also $5,35 \%$. . . . . . . . . . 160,5 ccm

2) für den schädlichen Raum noch weitere . . . . $39,8 \mathrm{ccm}$

zusammen $\ldots 200,3 \mathrm{ccm}$

also Menge des zugeströmten Sauerstoffs . . . . . . . . $\overline{2798,9 \mathrm{ccm}}$

Aus diesen Daten berechnet sich folgende Sauerstoffbilanz für die Luft des Apparates:

Anfangs im Apparat atmosphärische Luft, 20,95\%, also . . 4369,3 ccm 0

Zugeströmt während des Versuches . . . . . . . . . $\frac{2798,9 n n}{7168,2 \mathrm{ccm} 0}$

Verbraucht während des Versuches. . . . . . . . . $\frac{3555,5, n n}{3612,7}$

Also bleiben am Schluss des Versuchs im Apparat . . . . $\frac{3612,7}{36 m ~} 0$

Für die Zusammensetzung der Luft im Thierrecipienten am Schluss des Versuches berechnet man daraus einen Sauerstoffgehalt von . . . 17,46\%, während nach obiger Analyse gefunden waren . . . . . . . . 17,52\%.

Respiratorischer Quotient.

Der Sauerst offverbrauch betrug nach obiger Rechnung . . . . . . . . . . $3555,5 \mathrm{ccm}$

Für die Kohlensäureproduction wurde erbalten

1. in den vier Ventilen absorbirt $4540,5 \mathrm{ccm}$

2. in der Luft des Apparates zurückgeblieben . . . . $\frac{366,3 \text { ᄁ }}{\text { zusammen }} 4906,8$

Respiratoriseher Quotient $\frac{4906,8}{3555,5}=1,380$.

Der Versuch dauerte 32 Minuten; auf

1 Stunde berechnet, würde das Thier

erzeugt haben . . . . . . . . $9200 \mathrm{ccm}$ Kohlensäure

und verbraucht haben . . . . 6667 "Sauerstoff. 
Auf $1 \mathrm{~kg}$ Thier und 1 Stunde berechnet ist die Kohlensäurebildung . . . . . . . . . . . $1925 \mathrm{ccm}$ der Sauerstoffverbrauch . . . . . . . . 1395 "

2. Versuch. 18. November 1893.

Thier Nr. I. Gewicht des Thieres (am 17. Nov.): 5800 g. - Das Thier war Morgens, Vormittags und Nachmittags gefüttert.

- In den Kaliventilen $120 \mathrm{ccm}$ conc. Kalilauge.

Anfang des Versuches $4 \mathrm{~h} 17^{\prime} 30^{\prime \prime}$

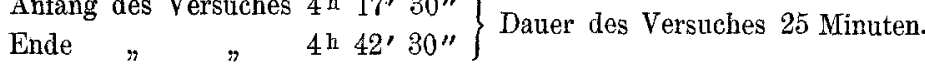

Barometer (auf $0^{0}$ reduc.) $736,0 \mathrm{~mm}$.

Temperatur des Versuchszimmers (neben dem Sauerstoffbehälter gemessen) am Anfang des Versuches . . . . . . 10,30,

$"$ Ende $" \quad$....... 10,40.

Temperatur des Wassers im grossen Wasserreservoir $10,0^{\circ}$.

Temperatur der Luft im Thierrecipienten:

beim Einsetzen des Thieres $11,1^{\circ} \mid$ Temperaturzunahme während des am Ende des Versuches. . 12,80 $\}$ Versuches 1,70.

Sauerstoffverbrauch, direct gemessen, auf $0^{\circ}, 760 \mathrm{~mm}$ Druck reducirt, $2875,8 \mathrm{ccm}$.

Kohlensäure-Erzeugung. Inhalt der vier Ventile auf $2000 \mathrm{ccm}$ gebracht. Davon zwei Proben zur Kohlensäurebestimmung benutzt.

1. Analyse. $40 \mathrm{ccm}$ der verdünnten Lauge enthalten $81,300 \mathrm{ccm}$ Kohlensäure das macht auf den Inbalt der vier Ventile $4065 \mathrm{crm} \mathrm{CO}_{2}$

2. Analyse. $45 \mathrm{ccm}$ der verdünnten Lauge enthalten $91,796 \mathrm{ccm} \mathrm{CO}_{2}$ das macht auf den Inhalt der vier Ventile $4079,8 \mathrm{ccm} \mathrm{CO}_{2}$

Kohlensäuregehalt der vier Ventile im

Mittel . . . . . . . . . . . . . 4072,4 $\mathrm{ccm}$

Je $1 \mathrm{ccm}$ der benutzten $120 \mathrm{ccm}$ conc.

Kalilauge enthielt $3,947 \mathrm{ccm}$ präf. $\mathrm{CO}_{z} \cdot . \quad 473,6 \mathrm{ccm}$

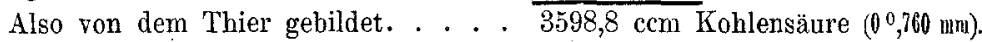

Anmerkung: Bei dem Versuch spritzte aus dem Ventil III in die Kugel $v$ etwas Kalilange über; dadurch gingen einige ccm Kalilauge verloren, die überdies noch sehr reich an Kohlensäure gewesen sein mïssen, weil der aus dem Thierrecipienten kommende Luftstrom zuerst mit dieser Lauge in Berührung kam. Der Kohlensäurewerth ist also in Wirklichkeit noch höher gewesen als 3598,8. Da sich aber dieses Mehr nicht abschätzen lässt, so behalte ich diesen Werth bei.

Analysen der Luftproben. Es wurde zur Analyse nur der Inhalt der Kugel $h$ genommen. Derselbe enthielt Kohlensäure 1,65\%. Brennbare Gase konnten nicht nachgewiesen werden $(25,652 \mathrm{ccm}$ Gas mit einer angemessenen Menge Knallgas verpufft gab 25,671 ccm, also keine Contraction). Die Sauerstoffanalyse ergab $18,46 \%$ Sauerstoff im kohlensäurefreigemachten Gas, also für die kohlensäurehaltige Luft berechnet $18,16 \%$. Für die Zusammensetzung der Luft am Ende des Versuches finden wir also: 


$$
\begin{array}{lr}
\text { Kohlensäure } & 1,65 \\
\text { Sauerstoff } & \mathbf{1 8 , 1 6}
\end{array}
$$

Sauerstoff.

In der Kupferwanne des Thierrecipienten befanden sich 12 Liter Wasser. - Der gesammte Luftinhalt des Thierrecipienten war 19,0 Liter, wovon 2 Liter auf den Raum jenseits der Ventile kommen. Der Luftinhalt des Apparates, auf $0^{0}, 760 \mathrm{~mm}$ reducirt, beträgt zu Anfang des Versuches 17,682 Liter

$$
\text { "Ende " " } 17,577 \text { " }
$$

Für den Sauerstoffrerbrauch ist zu berechnen:

1) die direct gemessene Menge. . . . . . . . . . . . 2875,8 ccm

2) Correctur für Temperaturerhöhung . . . . . . . . 105,0 ccm

3) Correctur für Kohlensäure

a) für den grossen Raum 15,727 Liter mit 1,65\% $=259,5 \mathrm{ccm}$

b) für den kleinen Raum 1,850 Liter mit $0,825 \%=15,3 \mathrm{ccm}$

zusammen $\overline{274,8 \mathrm{ccm}}$

Abzug für $\mathrm{CO}_{2}$ der atm. Luftam Anfang des Versuchs $7,1 \mathrm{ccm}$

bleiben . . . 267,7 ccm

Gesammtverbrauch an Sauerstoff . . . . . . . . . $\frac{267,73248 \mathrm{ccm}}{3248}$

Für den zúgeströmten Sauerstoff erhält mạn obige . . 2875,8 ccm

Davon ist abzuziehen:

1) für diejenige Menge, die nicht Sauerstoff war,

$5,37 \%$ dieser Menge . . . . . . . . . 154,4 ccm

2) für den "schädlichen Raum" . . . . . . . . 38,0 "

zusammen abzuziehen. .... $192,4 \mathrm{ccm}$

Also Menge des zugeströmten Sauerstoffs . . . . . . . . . . $\frac{192,4 \mathrm{~cm}}{2683,4 \mathrm{~cm}}$

Aus diesen Daten berechnet sich folgende Sauerstoffbilanz für die Luft des Apparates:

Anfangs im Apparat atmosphärische Luft $(20,95 \%$

Sauerstoff), also . . . . . . . . . 3704,4 ccm Sauerstoff

Zugeströmt während des Versuches . . . . . . . $\frac{2683,4 ;}{6387,8 \mathrm{ccm} \text { Sauerstoff }}$

Verbraucht während des Versuches . . . . . . . . 3248,5,

Also bleiben am Schlusse des Versuches im Apparat . $3139,3 \mathrm{ccm}$ Sauerstoff

Für die Zusammensetzung der Luft am Schlusse des Versuches (im grossen Raum des Thierrecipienten) berechnet man daraus einen Sauerstoffgehait von $17,84 \%$.

Gefunden wurde durch die Analyse $18,16 \%$.

\section{Respiratorischer Quotient.}

Der Sauerstoffverbrauch betrug nach obiger Rechnung $3248,5 \mathrm{ccm}$. Für die Kohlensäureproduction wurde erhalten: 
1. in den Ventilen absorbirt ....... . $3598,8 \mathrm{~cm}$ wobei $\mathrm{zu}$ bemerken ist, dass diese Zahl wegen des oben erwähnten Verlustes wahrscheinlich noch $\mathrm{zu}$ klein ist,

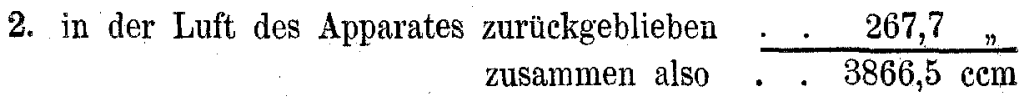
Respiratorischer Quotient $\frac{3866,5}{3248,5}=1,190$.

Der Versuch dauerte 25 Minuten; auf 1 Stunde berechnet, würde das Thier verbraucht haben $7796 \mathrm{ccm}$ Sauerstoff und erzeugt haben $9280 \mathrm{ccm}$ Kohlensäure.

Auf $1 \mathrm{~kg}$ Thier und 1 Stunde berechnet beträgt der Sauerstoffverbrauch . . . . $1471 \mathrm{ccm}$ die Kohlensäure-Erzeugung . . . $1751 \mathrm{ccm}$.

3. Versuch. 7. December 1893.

Thier Nr. I. Gewicht des Thieres 6600 g. Fütterung Morgens, Vormittags und Nachmittags.

In den Kalilaugeventilen je $80 \mathrm{ccm}$ conc. Kalilauge, zusammen $320 \mathrm{ccm}$.

Anfang des Versuches 2 h $24^{\prime} 30^{\prime \prime}$ | Dauer des Versuches 52 Minuten Ende " $\quad 3$ h $\left.17 \prime 15^{\prime \prime}\right\} \quad 45$ Secunden

Barometer (auf $0^{\circ}$ reduc.) $752,5 \mathrm{~mm}$.

Temperatur des Versuchszimmers (am Sauerstoffbehälter) 6,40. Temperatur des Wassers der grossen Zinkwanne $10^{\circ}$.

Temperatur im Thierrecipienten

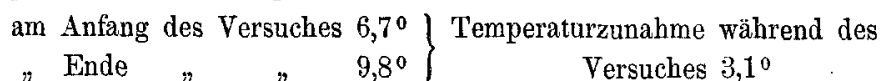

Temperatur des Wassers im Thierrecipienten am Ende des Versuches 9,50. Sauerst off verbrauch direct gemessen, auf $0^{3}, 760 \mathrm{~mm}$ reducirt, $6925 \mathrm{ccm}$.

Kohlensäureproduction. Inhalt der vier Ventile auf $4000 \mathrm{ccm}$ gebracht, davon zwei Proben zur Koblensäurebestimmung benutzt.

1. Analyse. $25,3 \mathrm{ccm}$ dieser verdünnten Lauge enthalten $63,981 \mathrm{ccm}$ Kohlensäure

das macht auf den Inhalt der vier Ventile 10115,4ccmKohlensäure

2. Analyse. $40 \mathrm{ccm}$ der verdünnten Lauge enthalten $101,087 \mathrm{ccm}$ Kohlensäure das macht auf den Inhalt der vier Ventile $10103,7 \mathrm{ccm}$ Kohlensäure

Inhalt der Ventile im Mittel . . . 10109,5 ccm Kohlensäure

Je $1 \mathrm{ccm}$ der benutzten $320 \mathrm{ccm}$ Kalilauge enthält präformirt $4,173 \mathrm{ccm}$ Kohlen-

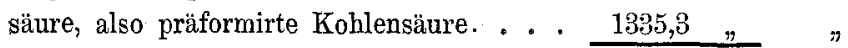
Also von dem Thier gebildet . . . $\frac{1874,2 \mathrm{ccm}}{8770 h l e n s a ̈ u r e ~}(00,760 \mathrm{~mm})$. 
In diesem Versuche wurde auch das im Thierrecipienten befindliche Wasser, welches 12 Liter betrug, vor und nach dem Versuch auf seinen Gehalt an Kohlensäure untersucht.

$200 \mathrm{ccm}$ Wasser nach dem Versnch enthielten. . . 2,670 $\mathrm{ccm} \mathrm{CO}_{2}$ $200 "$ vor $" . \quad \ldots \quad$. . . . 1,748, \#,

Von $200 \mathrm{ccm}$ Wasser wurden demnach während des

Versuches aufgenommen . . . . . . $0,922 \mathrm{ccm} \mathrm{CO}_{2}$

Auf die im Apparat vorhandenen 12 Liter würde das $55,3 \mathrm{ccm}$ Kohlensäure ausmachen.

Die in dem Wasser absorbirte Kohlensäuremenge ist also im Vergleich zu der Gesammtmenge an producirter Kohlensäure nur sehr gering, nämlich $55,3 \mathrm{ccm}$ gegenüber $8774,2 \mathrm{ccm}$. Das Plus an Kohlensäure, welches dem Inhalt der Ventile noch zuzurechnen ist, beträgt also nur ca. 0,6 Procent der ganzen Menge. Es ist daher wohl gerechtfertigt, wenn in den übrigen Versuchen diese Menge vernachlässigt wurde.

\section{Analysen der Luftproben.}

Die Kohlensäure-A naly se ergab in der Luft der Kugel $h 1,15 \%$ Kohlensäure, in der Kugel $v$ 1,42\% Kohlensäure.

Von brennbaren Gasen liessen sich auch in diesem Versuche höchstens Spuren nachweisen. Es gaben nämlich $32,559 \mathrm{ccm}$ Luft aus Kugel $v$ mit $16 \mathrm{ccm}$ elektrolyt. Knallgas verpufft eine Contraction von $0,055 \mathrm{ccm}, 19,443 \mathrm{ccm}$ Luf́t aus Kugel $h$ mit $9 \mathrm{ccm}$ Knallgas verpufft eine Contraction von $0,039 \mathrm{ccm}$; beide Contractionen liegen der Fehlergrenze so nah, dass ich aus denselben keine sicheren Schlüsse auf das Vorhandensein brennbarer Gase ziehen möchte. (Jedenfalls ist der Gehalt an solchen unter $0,15 \%$.)

Sauerstoffanalyse. Die Luftprobe aus Kugel $v$, kohlensäurefrei gemacht, ergab nach einer Analyse 14,56\% Sauerstoff, nach einer zweiten 14,47\% Sauerstoff, im Mittel $14,52 \%$. Auf kohlensäurehaltige Luft $\left(1,42 \% \quad \mathrm{CO}_{2}\right)$ gerechnet $14,31 \%$. - Die Luftprobe ans Kugel $h$, kohlensäurefrei gemacht, enthielt 14,29\% Sauerstoff und auf kohlensäurehaltiges Gas gerechnet $\left(1,15 \% \mathrm{CO}_{2}\right)$, $14,13 \%$. Das Resultat der Luftanalysen ist demnach folgendes:

$$
\text { Kugel } v
$$

(d. h. rorderer Theil des Apparates)

Kohlensäure $1,42 \%$,

Sauerstoff . 14,31\%.
Kugel $h$

(d. h. hinterer Theil des Apparates)

Kohlensäure $1,15 \%$,

Sauerstoff . 14,13\%.

Als mittlere Zusammensetzung ist also für die Luft des Thierrecipienten anzunehmen:

$$
\begin{aligned}
& \text { Kohlensäure } 1,29 \% \text {, } \\
& \text { Sauerstoff . 14,22\%. }
\end{aligned}
$$

Die Analysen des Gases im Sauerstoffbehälter ergaben 88,38 bezw. $88,76 \%$ Sauerstoff, im Mittel $88,57 \%$ Sauerstoff.

Der Sauerstoff war vor der Benutzung mehrere Wochen in einem Gasometer aus Eisenblech aufbewahrt worden, welches wohl nicht ganz dicht gewesen sein muss; daher die grössere Verunreinigung durch atmosphärische Luft. Daraus 
erklärt sich auch die Abnahme des Sauerstoffgehaltes im Thierrecipienten bis auf 14,22\%. Bei den späteren Versuchen wurde daher der Sauerstoff stets frisch bereitet.

In der Kupferwanne des Thierrecipienten befanden sich 12 Liter Wasser. Der gesamminte Luftinhalt des Apparates, auf $0^{0}, 760 \mathrm{~mm}$ reducirt, betrug

am Anfang des Versuches . . . . . . . . . 16,901 Liter

"Ende " \#. . . . . . . . . . 16,727

Für den Sauerstoffverbrauch ist zu berechnen:

1) die direct gemessene Menge. . . . . . . . . . . . $6925 \mathrm{ccm}$

2) Correctur für Temperatursteigerung. . . . . . . . . . . 174 "

3) Correctur für Kohlensäure

a) für den grossen Raum 14,816 Liter mit 1,29\%

Kohlensäure. . . . . . . . . . . 191,1 ccm

b) für den kleinen Raum 1,911 Liter mit $0,65 \%$

Kohlensäure. . . . . . . . . . . $\frac{12,4, "}{203,5 \mathrm{ccm}}$

Abzug für Kohlensäure der atmosph. Luft . . 6,8 ,

bleiben... 196,7 ,

Gesammtverbrauch an Sauerstoff . . . . . . . . . . $7295,7 \mathrm{ccm}$

Für den zugeströmten Sauerstoff erhält man obige. $6925 \mathrm{ccm}$

Davon ist abzuziehen:

1) für diejenige Gasmenge, die nicht Sauerstoff war,

$11,43 \%$ jener Menge. . . . . . . . . 791,5 cem

2) für den "schädlichen Raum" . . . . . . . . 35,1 "

Zusammen abzuziehen. . . . . . . . . . $\frac{826,6 \mathrm{ccm}}{6098,4 \mathrm{ccm}}$

Also Menge des zugeströmten Sauerstoffs

Aus diesen Daten berechnet sich folgende Bilanz für den Sauerstoff im Apparat:

Anfangs im Apparat atm. Luft (mit 20,95\% 0), also . $3540,8 \mathrm{ccm}$ Sauerstoff

Zugeströmt während des Versuches . . . . . . . . $\frac{6098,4, ~}{9639,2 \mathrm{ccm} \text { Sauerstoff }}$

Verbraucht während des Versuches . . . . . . . . $\frac{7295,7}{2343,5 \mathrm{ccm} \text { Sauerstoff }}$
Also bleiben am Schluss des Versuches im Apparat. .

Für die Zusammensetzung der Luft im Apparat be-

rechnet sich daraus . . . . . . . . 14,00\% Sauerstoff,

Durch die Analyse der Luftproben wurde gefunden. 14,22\% Sauerstoff.

Respiratorischer Quotient.

Der Sauerstoffverbrauch des Thieres betrug nach obiger Rechnung . . . . . . . . . . 7295,7 cem

Für die Kohlensäureproduction wurde erhalten: 
1. in den vier Ventilen absorbirt . . $8774,2 \mathrm{ccm}$

2. im Wasser des Apparates absorbirt 55,3 "

3. in der Luft des Apparates zurückgeblieben . . . . . . . 196,7, zusammen $9026,2 \mathrm{ccm}$.

Respiratorischer Quotient $\frac{9026,2}{7295,7}=1,237$.

Der Versuch dauerte 52,75 Minuten; auf eine Stunde berechnet, würde das Thier

8298 cem Sauerst off verbraucht und 10267 "Kohlensäure erzeugt haben.

Auf $1 \mathrm{~kg}$ Thier und eine Stunde berechnet, beträgt der verbrauchte Sauerstoff $1257 \mathrm{ccm}$, die erzeugte Kohlensäure 1556. "

\section{Versuch, 19. December 1893.}

Thier Nr. I. Hungerversuch. Gewicht des Thieres 6090 g. Das Thier hungert seit dem 13. December und hat während dieser Zeit von $6570 \mathrm{~g}$ auf $6090 \mathrm{~g}$ an Gewicht abgenommen.

In den vier Kaliventilen je $75 \mathrm{ccm}$ conc. Kalilauge, zusammen also $300 \mathrm{ccm}$. $\left.\begin{array}{l}\text { Anfang des Versuches } 2^{\text {h }} 54^{\prime} 5^{\prime \prime} \\ \text { Ende } \quad 3 \text { h } 59^{\prime}\end{array}\right\}$ Dauter des Versuches $64^{\prime} 55^{\prime \prime}$.

Barometer (auf $0^{\circ}$ reducirt) $751,1 \mathrm{~mm}$.

Temperatur im Versuchszimmer (neben dem Sauerstoffbehälter gemessen) 9,1 0

Temperatur im Thierrecipienten am Anfang des Versuches $9,1^{\circ}$

Temperatur im Thierrecipienten am Ende des Versuches $10,8^{\circ}$

Temperatur des Wassers im Thierrecipienten am Anfang des Versuches 9,1 . " $" \quad " \quad$ "Ende " $" 10,6^{\circ}$.

Temperatur des Wassers in der grossen Zinkwanne $9,6^{\circ}$.

Sauerstoffrerbrauch nach directer Messung durch die "Saterstoff messenden Flaschen", auf $0^{\circ}$ und $760 \mathrm{~mm}$ Druck reduc., 6845,8 ccm.

'Kohlensäure-Erzeugung." Inhalt der vier Ventile auf $2000 \mathrm{ccm}$ gebracht, davon genommen zur

1. Analyse $25 \mathrm{ccm}$. Dieselben enthalten $96,663 \mathrm{ccm}$ Kohlensäure, das macht auf den Inhalt der vier Ventile 7733,04 ccm.

2. Analyse $25 \mathrm{ccm}$. Dieselben enthalten $97,065 \mathrm{ccm}$ Kohlensäure, das macht auf den Inhalt der vier Ventile $7765,20 \mathrm{ccm}$. 
Kohlensäure-Gehalt der vier Ventile im Mittel $7749,1 \mathrm{ccm}$ Kohlensäure

Je $1 \mathrm{ccm}$ der benutzten concentrirten Kaalilauge enthält $9,096 \mathrm{ccm}$ Kohlensäure. Das macht auf $300 \mathrm{ccm}$ concentrirter Kalilauge . . . . . . 2728,8 ccm präf. Kohlensäure

Also vom Thier gebildet. . . . . . . 5020,3 ccm Kohlensäure

\section{Analysen der Luftproben.}

$\mathrm{Zu}$ Kohlensäure-Analysen wurde nur eine Luftprobe aus der Kugel $h$ benutzt. Dieselbe enthielt nach einer Analyse $0,627 \%$ Kohlensäure, nach einer anderen Analyse $0,634 \%$; im Mittel also 0,63\% Kohlensäure. (Die Kohlensäure-Analyse der Luftprobe aus Kugel $v$ verunglückte.)

Die Analyse auf brennbare Gase ergab, wie beim Hungerzuzstand nicht anders zu erwarten war, dass solche nicht vorhanden waren $(39,715 \mathrm{ccm}$ Gas, aus Kugel $v$ mit $11 \mathrm{ccm}$ elektrolyt. Knallgas verpufft, gaben $39,722 \mathrm{ccm}$, also keine Contraction).

Kohlensäurefreie Luft aus Kugel $h$ enthielt 18,50\% Sauerstoff, desgl. aus Kugel $v$ nach einer Analyse 18,40, nach einer anderen Analyse 18,30\% Sanerstoff. Für kohlensäurehaltige Luft $\left(0,63 \% \quad \mathrm{CO}_{2}\right)$ erhält man demnach für $h$ $18,38 \%$, für $v$ im Mittel $18,23 \%$ Sauerstoff.

Für die mittlere Zusammensetzung der Luft im Thierrecipienten folgt also daraus:

\section{Kohlensäure $0,63 \%$,}

Sauerstoff . 18,30\%.

Die Analyse des Gases im Sauerstoff behälter ergab 97,50\% Sauerstoff.

Im Thierrecipienten befanden sich 12 Liter destillirtes Wasser. - Der gesammte Luftinhalt des Apparates betrug, auf $0^{0}, 760 \mathrm{~mm}$ reducirt,

\section{zu Anfang des Versuches 17,213 Liter}

$$
\text { "Ende " } " 17,130 "
$$

Für den Sauerstoffverbrauch kommt in Betracht:

1) die direct gemessene Menge . . . . . . . . . . . . . 6845,8 ccm

2) Correctur für Temperaturerhöhung im Apparat . . . . . . 83,0 "

3) Correctur für Kohlensäure-Ansammlung

a) im grossen Raum 15,22 Liter mit 0,63\%

Kohlensäure . . . . . . . . . $95,9 \mathrm{ccm}$

b) im kleinen Raum 1,91 Liter mit 0,31\%

Kohlensäure . . . . . . . . . $\frac{5,9 n}{101,8 \mathrm{ccm}}$

Abzug für $\mathrm{CO}_{2}$ der atmosphärischen Luft. . $\frac{6,9 \#}{\text { bleiben } . \cdots \frac{94,9,}{7023,7},}$

Gesammtverbrauch an Sauerstoff . . . . . . . . . $\frac{97,9}{7023,7 \mathrm{ccm}}$

Für den zugeströmten Sauerstoff erhält man obige . . . . $6845,8 \mathrm{ccm}$

Davon ist abzuziehen:

1) für die 2,50\% dieser Menge, die nicht Sauerstoff

waren . . . . . . . . . . . . . $171,1 \mathrm{ccm}$

2) für den ,schädlichen Raum" . . . . . . . . . . 40,2

zusammen abzuziehen. . . . . . . . . $\frac{211,3}{6634,5 \mathrm{ccm}}$

Also Menge des zugeströmten Sauerstoffs ........ . $\frac{2634,5 \mathrm{ccm}}{6634,8}$ 
Aus diesen Daten ergibt sich folgende Sauerstoffbilanz für die Luft des Apparates :

Anfangs im Apparat atmosphärische Luft 17,213 Liter . . $3606,1 \mathrm{ccm} 0$

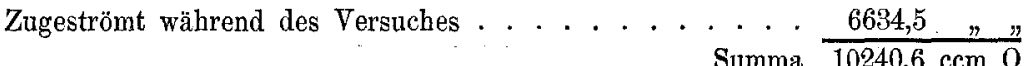

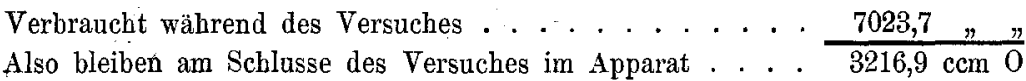

Für die Zusammensetzung der Luft am Schlusse des Versuches berechnet sich darans ein Sauerstoff-Gehalt von $18,76 \%$; gefunden wurde $18,30 \%$.

Respiratoriseher Quotient.

Der Sauerstoffverbrauch betrug nach obiger Rechnung . . . . . . . . . . $7023,7 \mathrm{~cm}$

Für die Kohlensäureproduction wurde erhalten:

1. absorbirt in den vier Kaliventilen $5020,3 \mathrm{ccm}$

2. in der Luft des Apparates verblieben 94,9 , zusammen 5115,2 ,

Demnach respiratorischer Quotient $\frac{5115,2}{7023,7}=0,728$.

Der Versuch dauerte 64,9 Minuten. In einer Stunde würde das Thier

verbraucht haben $6494 \mathrm{cem}$ Sauerstoff und erzeugt haben 4729 "Kohlensäure.

Auf $1 \mathrm{~kg}$ Thier und eine Stunde berechnet beträgt

der Sauerstoffverbrauch $1066 \mathrm{ccm}$ die Kohlensäure-Erzeugung 776,5 "

\section{Versuch. 10. Januar 1894.}

Thier Nr. II. Als ich das Thier erhielt, am 6. Januar 1894, wog dasselbe 3990 g. Das Thier hungerte bis zum Versuch. Gewicht am 9. Januar 3640 g. Am Versuchstag selbst wurde das Thier nicht gewogen, weil die Federn nass waren.

Da die Lufttemperatur draussen sehr kalt war, wurde das Versuchszimmer geheizt und die Temperatur desselben auf $14^{\circ}$ gehalten.

In den Kaliventilen befanden sich $300 \mathrm{~cm}$ concentrirter Kalilauge. Anfang des Versuches $12 \mathrm{~h} 5^{\prime} 0^{\prime \prime} \mid$ Dauer des Versuches 38,75 Ende " " $\left.12^{\mathrm{h}} 43^{\prime} 45^{\prime \prime}\right\} \quad$ Minuten

Der Versuch war ebenso wie der vorige auf einen Sauerstoffverbrauch von 7 Literflaschen berechnet, musste aber während des Verbrauchs der dritten Flasche unterbrochen werden, weil einer der beiden Aspiratorencylinder sprang. 
Barometer (auf $0^{\circ}$ reduc.) 760,3 .

Temperatur des Versuchszimmers $14,2^{\circ}$ (neben dem Sauerstoffbehäıter gemessen).

Temperatur im Kopfaufsatz des Thierrecipienten

am Anfang des Versuches $14,2^{\circ}$ | Temperatursteigerung während des $"$ Ende $\left." \quad 14,3^{\circ}\right\} \quad$ Versuches $0,1^{\circ}$.

Temperatur des Wassers im Thierrecipienten

unmittelbar vor dem Versuch $11,5^{\circ}$,

$$
\text { "nach " } " 12,2^{\circ} \text {. }
$$

Temperatur des Wassers der grossen Zinkwanne anfangs 9,0 $0^{\circ}$ am Ende 9,2 . Sauerst offyerbrauch, direct gemessen, auf $0^{\circ}$ und $760 \mathrm{~mm}$ reduc., 2531,5 .

Kohlensäure-Erzeugung. Inhalt der vier Ventile . $3361,1 \mathrm{~cm} \mathrm{CO}_{2}$

Davon präformirt in den $300 \mathrm{ccm}$ Kalilauge . . . . . . . . . . . . 1616,9 \# $1744,2 \mathrm{ccm} \mathrm{CO}_{2}$
Vom Thier gebildet.

\section{Analysen der Luftproben.}

Brennbare Gase fehlten in beiden Luftproben. Im Uebrigen ergaben die Analysen:

für Kugel $v$

Kohlensäure $\quad 0,24 \%$

Sauerstoff $\quad 20,08 \%$ für Kugel $h$

Kohlensäure $\quad 0,11 \%$

Sauerstoff $\quad 20,23 \%$.

Für die mittlere Zusammensetzung der Luft im Thierrecipienten also:

$$
\begin{array}{lr}
\text { Kohlensäure } & 0,18 \% \\
\text { Sauerstoff } & 20,16 \%
\end{array}
$$

Die Analyse des Gases im Sauerstoffbehälter ergab 98,22\%.

Im Thierrecipienten befanden sich 12 Liter Wasser. Der gesammte Luftinhalt des Apparates, auf $0^{\circ}, 760 \mathrm{~mm}$ reducirt, beträgt

$$
\begin{aligned}
& \text { zu Anfang des Versuches } 19,426 \text { Liter, } \\
& \text { zu Ende des Versuches } 19,419 \text { " }
\end{aligned}
$$

Für den gesammten Sauerstoffverbrauch erhält man

1. direct gemessen . . . . . . . . . . . . $2581,5 \mathrm{ccm}$

2. Correctur für Temperaturerhöhung . . . . . . . . 7,0 n

3. Correctur für Kohlensäure . . . . . . . . . . . . $\frac{25,4,}{2563,9 \mathrm{ccm}}$

Für die Menge des zugeströmten Sauerstoffs erhält man obige $2531,5 \mathrm{ccm}$.

Davon ist in Abzug zu bringen:

1. Für 1,78\% dieser Menge, die nicht Sauerstoff waren, $45,0 \mathrm{ccm}$

2. Für den schädlichen Raum . . . . . . . . . 40,5,

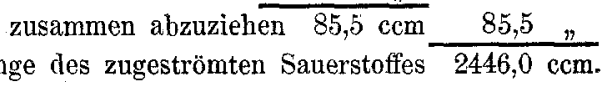


Aus diesen Daten berechnet sich folgende Sauerstoffbilanz für die Luft des Apparates:

Anfangs im Apparat 19,426 Liter atmosphärische Luft $=4069,7 \mathrm{ccm}$ Sanerstoff. Zugeströmt während des Versuches . . . · · $\frac{\cdot 2446,0}{\text { Summa }}$ "6515,7 ccm Sauerstoff.

Verbraucht während des Versuches . . . . . $\frac{2563,9,}{\text { Bleiben am Schlusse des Versuches im Apparat } 3951,8 \mathrm{ccm} \text { Sauerstoff. }}$

Für den procentischen Gehalt der Luft des Apparates am Schlusse des Versuches an Sauerstoff berechnet man daraus $20,35 \%$, während durch die Analyse gefunden wurde $20,16 \%$.

\section{Respiratorischer Quotient.}

Der Sauerstoffverbrauch betrug nach obiger Rechnung . . . . . . . . . . . . $2563,9 \mathrm{ccm}$

Für die Kohlensäure-Erzeugung wurde erhalten

1. in den vier Ventilen absorbirt . 1744,2 ccm

2. in der Luft des Apparates verblieben 25,4 ":

zusammen $1769,6 \mathrm{ccm}$

Respiratorischer Quotient $\frac{1769,6}{2563,9}=\mathbf{0 , 6 9 0}$.

Der Versuch dauerte 38,75 Minuten. In 1 Stunde würde daher das Thier

$$
\begin{aligned}
& \text { verbraucht haben } 3970 \mathrm{ccm} \text { Sacerstoff, } \\
& \text { erzeugt haben } 2740 \quad \text { Kohlensäure. }
\end{aligned}
$$

Das Thier wog $3640 \mathrm{~g}$. Daher würde $1 \mathrm{~kg}$ Thier in 1 Stunde verbraucht haben $1090,7 \mathrm{ccm}$ Sauerstoff erzeugt haben $\quad 752,7$, Kohlensäure.

\section{Versuch. 8. Februar 1894.}

Thier Nr. III. (Mästnngsversuch.) Gewicht des Thieres (Morgens 7 Uhr) 6050 g. Vor dem Versuch dreimalige Fütterung (71/4, 101/2, 2 Uhr).

In den Kaliventilen $250 \mathrm{ccm}$ concentrirte Kalilauge.

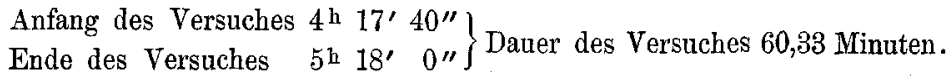

Barometer (auf $0^{\circ}$ reducirt) $761,7 \mathrm{~mm}$.

Temperatur des Versuchszimmers $19,1^{\circ}$ (neben dem Sauerstoff behälter gemessen).

Temperatur im Thierrecipienten am Anfang des Versuches 20,1.

$$
n \text {. } " \quad \text { Ende } " \quad, \quad 19,6^{\circ} \text {. }
$$


Die Temperatur der Iuft des Thierbehälters hat also während dieses Versuches eine geringe Abnahme erfahren, um $0,5^{\circ}$.

Temperatur des Wassers der grossen Zinkwanne $8,4^{\circ}$.

$" \quad " \quad$ im Thierrecipienten am Anfang des Versuches $18^{\circ}$.

Sauerstoffverbrauch, direct gemessen, $7157,6 \mathrm{ccm}$ bei $19,1^{\circ}, 761,7 \mathrm{~mm}$, auf $0^{\circ}$ und $760 \mathrm{~mm}$ reducirt, $6704,7 \mathrm{ccm}$.

Kohlensäure-Erzeugung. Kohlensäuregehalt des Inhaltes der vier Ventile 8786,4 bezw. 8792,2 ccm, im Mittel . . . . . . . . $8789,3 \mathrm{ccm}$.

Präformirt in den benutzten $250 \mathrm{ccm}$ Kalilauge . . . . . $1309,1 \mathrm{~m}$

Von dem Thier producirte Kohlensäure $\overline{7480,2 \mathrm{ccm}}$.

\section{Analysen der Luftproben.}

Brennbare Gase konnten auch in diesem Versuche nicht nachgewiesen werden. $(28,637 \mathrm{~cm}$ Gas aus der Kugel $v$ gaben nach Verpuffen mit $11,4 \mathrm{ccm}$ elektrolyt. Knallgas 28,635 ccm Gas, also keine Contraction.) Im Uebrigen ergâben die Analysen für die beiden Luftproben dieses Mal fast gleiche Zusammensetzung, nämlich :

\begin{tabular}{lrlr}
\multicolumn{2}{c}{ Kugel $v$} & \multicolumn{2}{c}{ Kugel $h$} \\
Kohlensäure & $1,26 \%$ & Kohlensäure & $1,29 \%$ \\
Sauerstoff & $19,16 \%$ & Sauerstoff & $19,17 \%$.
\end{tabular}

Mittlere Zusammensetzung also:

$$
\begin{array}{lr}
\text { Kohlensäure } & 1,275 \% \\
\text { Sauerstoff } & 19,165 \%
\end{array}
$$

Sauerstoffanalyse des Sauerstoffgases. Eine Probe des Gases aus dem Sanerstoffbehälter, unmittelbar vor dem Versuch aus dem Behälter entnommen, enthielt 97,75\% Sauerstoff, eine zweite Probe, unmittelbar nach dem Versuch entnommen, 97,88\% Sauerstoff, Mittel $97,82 \%$.

: I Der gesammte Luftinhait des Apparates, auf $0^{\circ}, 760 \mathrm{~mm}$ reducirt, betrug

zu Anfang des Versuches . . . . . . . . . . . . . . 16,888 Liter

"Ende " $"$. . . . . . . . . . . . . . 16,918"

Da die Temperatur der Luft des Apparates während dieses Versuches nicht zunahm, sondern im Gegentheil um $0,5^{\circ}$ abnahm, so hat das (auf $0^{\circ}, 760 \mathrm{~mm}$ reduc.) Volumen um einen geringen Betrag, nämlich um $30 \mathrm{ccm}$, zugenommen.

Für den gesammten Sauerstoffverbrauch erhält man folgende Berechnung:

1) die direct gemessene Menge . . . . . . . . . . $6704,7 \mathrm{~cm}$

2) Correctur für Temperatur-A bnahme . . . . . . . . - - 30,0 "

3) Correctur für Kohlensäureansammlung im Thierrecipienten $\frac{+196,5 \text {, }}{6871,2}$

Also Gesammtverbrauch an. Sauerstoff . $.6871,2 \mathrm{ccm}$

Für den zugeströmten Sauerstoff wird erhalten:

Obige Menge von . . . . . . . . . . . . . . 6704,7 ccm 
Davon ist in Abzug zu bringen:

1) 2,18 dieser Menge für den Antheil, der nicht

Sauerstoff war . . . . . . . $146,2 \mathrm{ccm}$

2) Für den schädlichen Raum • • • • • $\frac{39,6 \quad \text { \#usammen }}{\text { Zum }}$

Zusammen . $185,8 \mathrm{ccm}$

Bleiben für die Menge des zugeströmten Sauerstoffs . $6518,9 \mathrm{ccm}$

Aus diesen Daten berechnet sich folgende Sauerstoffbilanz für die Luft des Apparates:

Anfangs im Apparat 16,888 Liter atmosphärische Luft

(mit 20,95\% Sanerstoff) . . . . . . . . . $3538,0 \mathrm{ccm}$ Sauerstoff

Zugeströmt während des Versuches . . . . $\frac{.6518,9 \#}{.10056,9 \mathrm{ccm} \text { Sauerstoff }}$

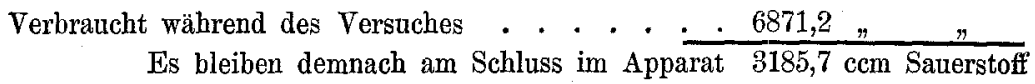

Für die Zusammensetzung der Luft im Thierrecipienten am Schluss des Versuches

berechnet man daraus einen Sauerstoffgehalt von . . . . . 18,82\%

während durch die Analyse gefunden wurde: . . . . . . . . 19,16\%

Respiratorischer Quotient.

Der gesammte Sauerst offverbrauch des Thieres betrug . . . . . . . . . . . . . . . 6871,2 ccm

Für die Kohlensäureproduction erhielt man in den vier Ventilen absorbirt .. . $7480,2 \mathrm{ccm}$ in der Luft des Apparates verblieben 196,5
zusammen Respiratorischer Quotient $\frac{7676,7}{6871,2}=1,117$.

Der Versuch danerte 60,33 Minuten. In 1 Stunde würde danach das Thier

an Sauerstoff verbraucht haben $6833,6 \mathrm{ccm}$

"Kohlensäure erzeugt haben 7634,7 "

Das Thier wog $6050 \mathrm{~g}$, demnach würde man erhalten für $1 \mathrm{~kg}$ Thier und 1 Stunde

$\begin{array}{ll}\text { Sauerstoffverbrauch } & 1129,5 \mathrm{ccm} \\ \text { Kohlensäure-Erzeugung } & 1261,9,\end{array}$

7. Yersuch. 19. Februar 1894.

Thier Nr. III (Mästungsversuch). Gewicht des Thieres 6990 g. Versuchszeit etwa $1^{1 / 2}$ Stunden nach der dritten Fütterung. 
In den Kaliventilen $290 \mathrm{ccm}$ concentrirte Kalilauge.

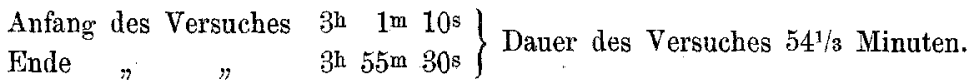

Barometer auf $\left(0^{\circ}\right.$ reducirt $) 767,3 \mathrm{~mm}$.

Temperatur des Versuchszimmers $17,6^{\circ}$ (neben dem Sauerstoff behälter gemessen).

Temperatur der Luft im Thierrecipienten (Kopfaufsatz des Apparates):

am Anfang des Versuches $\left.17,20^{\circ}\right\}$ Temperatursteigerung während des Ver-

"Ende " $\left." 17,35^{\circ}\right\}$ suches $0,15^{\circ}$.

Temperatur des Wassers im Thierrecipienten (12 Liter) vor dem Versuch $16,8^{\circ}$, nach dem Versuch $18,6^{\circ}$.

Temperatur des Wassers in der grossen Zinkwanne $8,8^{\circ}$.

Sa ue rstoffverbrauch, direct gémessen, auf $0^{\circ}, 760 \mathrm{~mm}$ reduc., $6789 \mathrm{ccm}$.

Kohlensäure-Erzeugung. Im Inhalt der 4 Kaliventile 9618,4 bezw. nach einer zweiten Analyse $9642,3 \mathrm{ccm}$ Kohlensäure.

im Mittel also. . . . . . . . . . . $9630,3 \mathrm{ccm}$

Die $290 \mathrm{ccm}$ concentrirte Kalilauge enthielten an

präformirter Kohlensäure $(4,033 \mathrm{ccm}$ pro

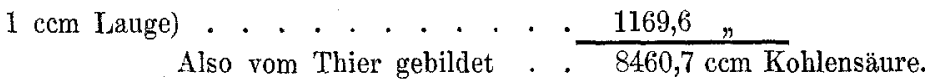

Analysen der Luftproben.

Brennbare Gase konnten wiederum nicht nachgewiesen werden. $(19,160 \mathrm{ccm}$ Gas aus der Kugel $h$, mit 6,04 ccm elektrolytischem Knallgas verpufft, gaben 19,179 $\mathrm{ccm}$ Gas, also keine Contraction.) Im Uebrigen ergaben die Gasanalysen:

Kugel $v$

Kohlensäure $2,33 \%$

Sauerstoff $17,80 \%$
Kugel $h$

Kohlensäure $2,55 \%$

Sauerstoff $17,29 \%$

Für die mittlere Zusammensetzung der Luft im Thierrecipienten erhält man danach :

Kohlensäure $2,44 \%$

Sauerstoff $\quad 17,55 \%$

Die Analyse des Gases im Sauerstoff behälter ergab 96,72\% Sauerstoff.

In der Kupferwanne des Thierrecipienten befanden sich 12 Liter destillirtes Wasser. - Der gesammte Luftraum des Thierrecipienten betrug, auf $0^{\circ}, 760 \mathrm{~mm}$ reducirt,

zu Anfang des Versuches . . . . . . . . . . . . 16,284 Liter

"Ende " $"$. . . . . . . . . . . . . $16,277 "$

Für den Sauerstoffverbrauch kommt in Betracht:

1) Die direct gemessene Menge . . . . . . . . . . 6789 cem

2) Correctur für Temperaturerhöhung . . . . . . . . . 7 "

3) Correctur für Kohlensäure-Ansammlung im Apparat. $\cdot \frac{367,5}{7163,5 \mathrm{ccm}}$
Gesammtverbrauch an Sauerstoff . . .

Für den zugeströmten Sauers toff sind zu berechnen obige $6789 \mathrm{ccm}$ 
Davon sind in Abzug zu bringen:

1) $3,28 \%$ dieser Menge, die nicht Sauerstoff waren $222,7 \cdot \mathrm{cm}$

2) Für den "schädlichen Raum" . . . . . . . 39,6,

Zusammen abzuziehen

Also bleiben für die Menge des zugeströmten Sauerstoffs $\quad 6526,7 \mathrm{ccm}$

Aus diesen Zahlen ergibt sich folgende Sauerstoffbilanz für die Luft des Apparates :

Anfangs im Apparat 16,284 Liter atmosph. Luft (20,95\%

Sauerstoff) . . . . . . . . . $3411,8 \mathrm{ccm}$ Sauerstoff

Zugeströmt während des Versuches . . . . $\frac{6526,7,}{\text { Summe } 9938,5 \mathrm{ccm} \text { Sauerstoff }}$

Verbraucht während des Versuches . . . . . . . 7163,5, , ;

Also verbleiben am Schluss des Versuchs im Apparat 2775,0 ccm Sauerstoff

Für den| Gehalt der Luft des Apparates am Schlusse des Versuches an Sauerstoff:

Berechnet man daraus . . . . . . . . . . . 17,02\% Sauerstoff

Durch die Analysen warden gefunden im Mittel . . . 17,55\% Sauerstoff.

Respiratorischer Quotient.

Der gesammte Sauerstoffyerbrauch betrug $7163,5 \mathrm{ccm}$ Die gesammte Kohlensäure-Erzeugung

1. die in der Kalilauge der Ventile absorbirte Menge . . . . . $8460,7 \mathrm{ccm}$

2. in der Luft des Apparates verbliebene Menge $\cdot \cdot$ zusammen $\cdot \frac{.}{.} 367.5$ " 8828,2 "

Respiratorischer Quotient $\frac{8828,2}{7163,5}=1,232$.

Der Versuch dauerte 54,33 Minuten. In 1 Stunde würde danach das Thier

verbraucht haben 7911,1 cem Sauerstoff und

erzeugt haben 9749,5, Kohlensäure.

Das Thier wog $6990 \mathrm{~g}$. Pro Kilo und Stunde würde danach das Thier

$1131,8 \mathrm{~cm}$ Sauerstoff verbraucht und

1394,7 "Kohlensäure erzeugt haben.

8. Versuch. 23. Februar 1894.

Thier Nr. III (Mästungsversuch). Gewicht des Thieres 7570 g. Versuch begonnen etwa 2 Stunden nach der dritten Fütterung.

In den Kaliventilen $300 \mathrm{ccm}$ concentrirte Kalilauge.

E. Pflüger, Archiv für Physiologie. Bd. 85 . 
Barometer (auf $0^{\circ}$ reducirt) $755,7 \mathrm{ccm}$.

Anfang des Versuches 5 h $19^{\prime} 00^{\prime \prime}$ | Dauer des Versuches 62,83

Ende " $\quad 6$ h 21'50" Minuten.

Temperatur des Versuchszimmers, am Anfang des Versuches neben dem Sauerstoff behälter gemessen, $19,4^{\circ}$ (am Ende des Versuches 19,9 ${ }^{\circ}$ ).

Temperatur im Thierrecipienten am Anfang des

Versuches $19,2^{\circ}$

Temperatur im Thierrecipienten am Ende des
Versuches $20,0^{\circ}$

Temperatur des Wassers im Thierrecipienten am Anfang 20,0 $21,4^{\circ}$. - Temperatur des Wassers in der grossen Zinkwanne $10^{\circ}$.

Sau ers toff e r brauch, direct gemessen, auf $0^{\circ}, 760 \mathrm{~mm}$ reduc., $6645,1 \mathrm{ccm}$.

Kohlensäure-Erzeugung. Inhalt der vier

Kaliventile . . . . . . . . . . . . 9061,0 ccm Kohlensäure

Präformirt in der Kalilauge $(4,08 \mathrm{ccm}$ in je $1 \mathrm{ccm}$

der concentrirten Lauge) . . . . . . . . . . . 1224,0 " "

Von dem Thier producirt . . . . . . . . $7837,0 \mathrm{ccm}$ Kohlensäure

Analysen der Luftproben.

Brennbare Gase waren auch in diesem Versuche nicht nachzuweisen; im Uebrigen ergaben die Analysen:

Kugel $v$

Kohlensäure $1,93 \%$

Sauerstoff. . $16,69 \%$.
Kugel $h$

Kohlensäure $\quad 1,92 \%$

Sauerstoff . $16,78 \%$.

Also für die mittlere Zusammensetzung der Luft im Thierrecipienten:

$$
\begin{aligned}
& \text { Kohlensäure } \begin{array}{r}
1,92 \% \\
\text { Sauerstoff } \quad 16,74 \%
\end{array}
\end{aligned}
$$

Die Analyse des Gases im Sauerstoffbehälter gab 95,60\% Sauerstoff.

In der Kupferwanne des Thierrecipienten befanden sich 12 Liter Wasser. Der gesammte Luftraum des Apparates, auf $0^{\circ}, 760 \mathrm{~mm}$ Druck reducirt, betrug am Anfang des Versuches 15,374 Liter,

$$
\text { " "Ende " " 15,337 " }
$$

Für den gesammten Sauerstoffverbrauch sind zu berechnen:

1) Die direct gemessene Menge . . . . . . . . . . 6645,1 ccm.

2) Correctur für die geringe Temperaturerhöhung . . . . . . 37,0 "

3) Correctur für während des Versuches in der Luft des Apparates

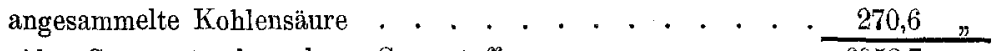

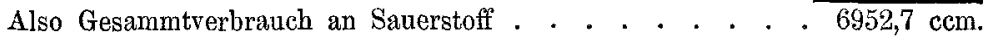

Fûr die Menge des zugeströmten Sauerstoffes erbält man obige 6645,1 "

Davon sind folgende Abzüge zu machen:

1) $4,4 \%$ dieser Menge, die nicht Sauerstoff waren, $=292,4 \mathrm{ccm}$.

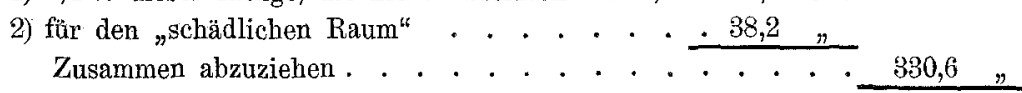

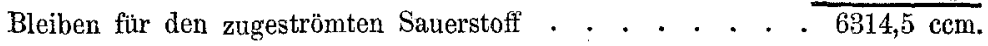


Aus diesen Daten ergibt sich für die Luft des Apparates folgende Sauerstoffbilanz:

Anfangs im Apparat vorhanden 15,374 Liter atmosphärische Luft (20,95\% Sauerstoff) . . . . 3220,9 ccm Sauerstoff.

Zugeströmt während des Versuches . . . . . . 6314,5

Summe . . . . . . . . . . . . . . $\frac{9585,4 \mathrm{ccm} \text { Sauerstoff. }}{958587}$

Verbraucht während des Versuches . . . . . . 6952,7

Bleiben am Schlusse des Versuches im Apparat. . 2582,7 ccm Sauerstoff.

Das macht auf die Luftmenge des Apparates berechnet $16,82 \%$, während durch die Analyse im Mittel gefunden wurde 16,74\%.

\section{Respiratorischer Quotient.}

Für den gesammten Sauerstoffverbrauch wurde gefunden . . . . . . . . . . . 6952,7 ccm

Für die gesammte Kohlensäure-Erzeugung erhält man

1. die in den vier Ventilen absorbirte Menge . . . . . . . . . . 7837,0 cem

2. die in der Luft des Apparates zurückgebliebene Menge . . . . 270,6 ,

Man erhält also den zusammen 8107,6 respiratorischen Quotienten $\frac{8107,6}{6952,7}=1,166$.

Der Versuch dauerte 62,83 Minuten. In 1 Stunde würde demnach das Thier

verbraucht haben $6639,5 \mathrm{ccm}$ Sauerstoff und erzeugt haben 7742,4 " Kohlensäure

Das Thier wog $7570 \mathrm{~g}$. Pro Kilo und Stunde würde danach betragen

$$
\begin{aligned}
& \text { der Sauerstoffverbrauch } 877,1 \mathrm{ccm} \\
& \text { die Kohlensäure-Erzeugung } 1022,8 \text { " }
\end{aligned}
$$

Die Resultate der acht Respirationsversuche sind in der nachfolgenden Tabelle (S. 396) übersichtlich zusammengestellt. 


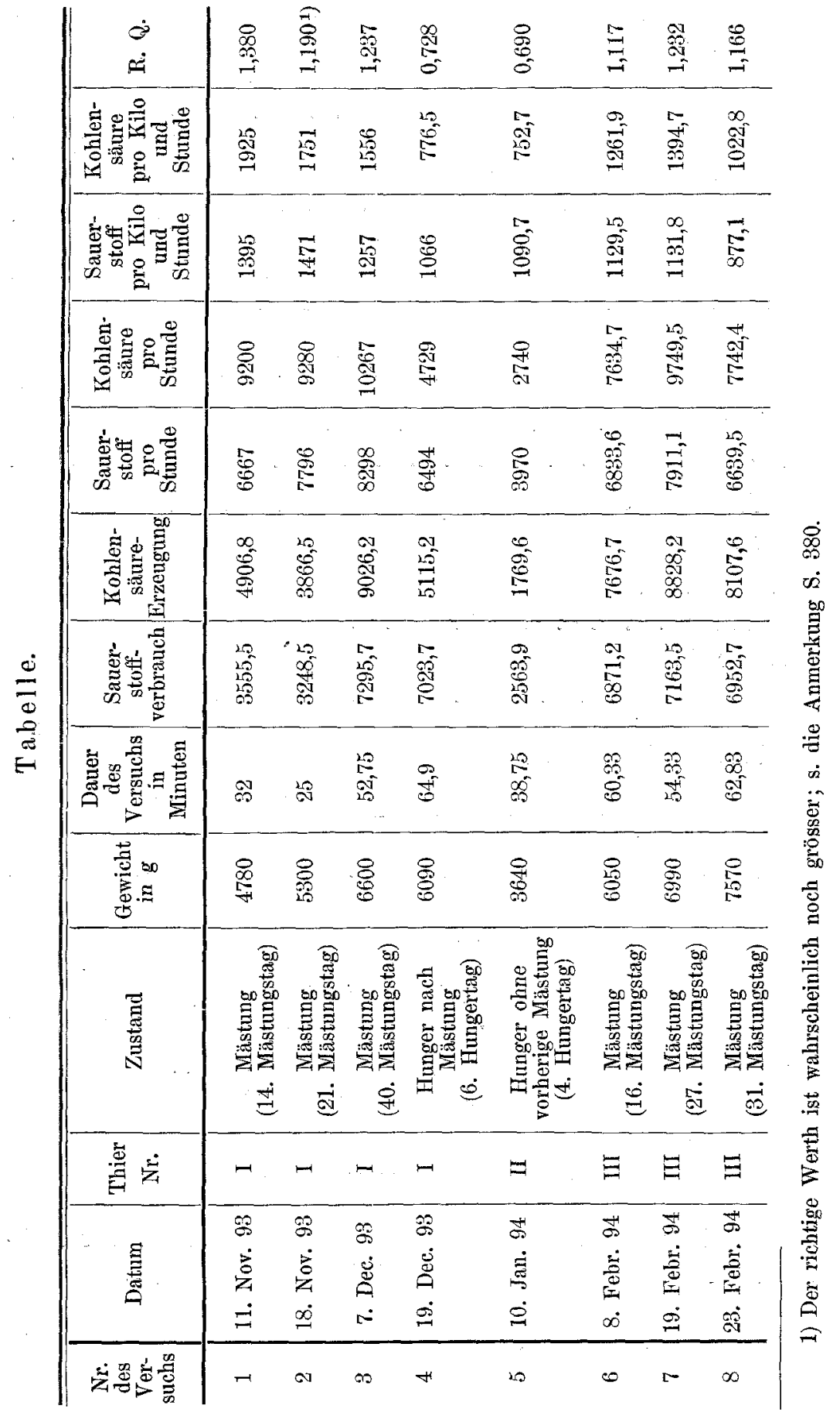


Während sich bei den Hungerversuchen Werthe für den respiratorischen Quotienten finden, welche dem Hungerzustande durchaus entsprechen, nämlich 0,690 und 0,728 , sehen wir, dass in allen Mästungsversuchen die Einheit erheblich überschritten wird; die Werthe liegen zwischen 1,117 und 1,380. Wenn wir zunächst die Ergebnisse beim Versuchsthier I (Versuch 1 bis 4) in's Auge fassen, so finden wir, dass der Sauerstoffverbrauch pro Stunde ziemlich verschieden ist, und zwar steigt derselbe während der Mästungszeit von $6667 \mathrm{ccm}$ auf $8298 \mathrm{ccm}$. Wenn die Gewichtszunahme des Thieres nur auf Fettansatz beruhte, so wäre es, da man annehmen darf, dass die Stoffwechselgrösse eines Thieres durch Ansatz von Körperfett nicht wächst, zu erwarten, dass der Sauerstoffbedarf keine Steigerung erführe. Indessen hat man hier zu bedenken, dass bei der vorgenommenen Mästung mit Roggenmehl in so grossen Quantitäten auch eine Fleischmast möglich ist, also eine Vermehrung der stickstoffhaltigen Körpersubstanz des Thieres und damit eine Steigerung des Nahrungsbedarfes. Dafür würde auch der Umstand sprechen, dass das gemästete Thier (nach sechstägigem Hunger) einen Sauerstoffverbrauch im Hungerzustand hat, der mit 6494.cem pro Stunde nur wenig hinter $6667 \mathrm{ccm}$, der entsprechenden Zahl des am Anfang der Mästungsperiode liegenden ersten Fütterungsversuches zurückbleibt.

Vergleichen wir bei Thier Nr. I den niedrigsten und den höchsten Werth für den stündlicheu Sauerstoffverbrauch, so finden wir den ersteren bei dem Hungerversuch (Nr. 4) mit $6494 \mathrm{ccm}$, den letzteren beim Mästungsversuch Nr. 3 mit $8298 \mathrm{ccm}$; das entspricht einer Steigerung von Hunger zu Mästung um nahezu $28 \%$. Ungleich grösser aber ist in denselben beiden Versuchen die Differenz der Kohlensäureproduction, welche 4729 bezw. $10267 \mathrm{ccm}$ beträgt. Also bei Vergleichung von Hunger und Mästung haben wir gegenüber einer Steigerung des Sauerstoffverbrauches um ca. $28 \%$ eine Steigerung der Kohlensäureproduction um ca. $117 \%$. Diese grosse Differenz zwischen dem Verhalten des Sauerstoffs und der Kohlensäure ist natürlich zum Thej1 hervorgebracht durch denjenigen Zuwachs der letzteren, welcher durch den Uebergang von Hunger zu Kohlehydratfütterung bedingt ist, zum Theil aber auch durch denjenigen Zuwachs, der aus der Umbiliung von Kohlehydrat zu Fett herstammt, und den wir oben als "atypische" Kohlensäure bezeichnet haben. 
Beim Thier Nr. I betrug nach der Fütterungs- und Körpergewichtstabelle S. 360 die durchschnittliche tägliche Gewichtszunabme 61 g. Wenn wir dieselbe ganz auf Fett beziehen, so begehen wir ja vielleicht einen kleinen Febler, da es möglich ist, dass das Thier auch etwas Fleisch angesetzt hat. Nehmen wir aber an, dass das Thier $61 \mathrm{~g}$ Fett täglich aus Kohlehydrat gebildet habe, so entspricht das nach der in der Einleitung gegebenen Betrachtungsweise pro Tag 36 Liter "atypischer Kohlensäure". Der Sauerstoff bedarf nes Thieres beträgt nach dem Durchschnitt der drei Mästungsversuche 182 Liter pro Tag. Nach dem früher Gesagten gibt das einen Zuwachs des respiratorischen Quotienten um $\frac{36}{182}=0,1978$ oder rund 0,2. Dieser Zuwachs könnte den respiratorischen Quotienten äussersten Falles bis auf 1,2 in die Höhe treiben. Wenn wir in den Versuchen noch höhere Werthe finden, so ist das leicht daraus zu erklären, dass einmal die Versuchstage möglichst günstig gewählt wurden, so dass wahrscheinlich die Fettbildung an diesen Tagen den Durchsehnitt übertraf, und dass ferner auch noch, wie früher bereits erwähnt, an den einzelnen Tagen eine möglichst günstige Stunde für die Versuche ausgewählt wurde.

Keinesfalls können aber die hohen respiratorischen Quotienten in unseren Versuchen durch Abnahme des Sauerstoffverbrauchs erklärt werden, wie es die alte Liebig'sche Vorstellung erfordern würde; denn wir sehen, dass die Zahlen für den Sauerstoffverbrauch während der Mästungszeit nicht klein sind, dass sie im Gegentheil gegen den Hungerzustand diejenige Vergrösserung aufweisen, welche bei dem Vergleich von Hunger und Fütterung zu erwarten ist.

Bei dem Thier Nr. III (Versuche 6, 7 und 8) zeigte der Sauerstoffverbrauch des Thieres, wenn wir Versuch 6 und 7 vergleichen, wieder eine Zunahme, um dann aber bei Versuch 8 wieder abzunehmen. Die Zunahme würde, wie bei Thier I, durch gleichzeitig mit der Fettmast stattfindende Fleischmast zu erklären sein; ob für die Abnahme bei Versuch 8 die bei dem fortschreitenden Mästungszustand zunehmende Trägheit des Thieres verantwortlich gemacht werden kann, möge dahingestellt bleiben.

Laut Fütterungs- und Körpergewichtstabelle S. 361 betrug die durchschnittliche Zunahme des Thieres Nr. III $72 \mathrm{~g}$; unter Zugrundelegung des Durchsehnittes der drei Mästungstage ergibt sich ein Sauerstoffbedarf des Thieres von ca. 170 Litern täglich. $72 \mathrm{~g}$ Fett- 
bildung aus Kohlehydrat würden 42,5 Liter "atypische Kohlensäure“ entsprechen, und das würde einen Zuwachs des respiratorischen Quotienten von $\frac{42,5}{170}=0,25$ bedingen.

Der durchschnittliche respiratorische Quotient während der Mästungsperiode könnte dadurch bis zum Werthe 1,25 in die Höhe getrieben werden. In Versuch 7 wurde dieser Werth fast genau: erreicht; während im 6. und 8 . Versuche die Werthe 1,117 und 1,166 beobachtet wurden.

In der drittletzten und vorletzten Colonne der Tabelle finden sich die Zahlen für den Sauerstoffverbrauch und die Kohlensäureproduction der Thiere auf 1 Stunde und $1 \mathrm{~kg}$ Körpergewicht bezogen. Ich will bemerken, dass diese auf die Einheit des Körpergewichts bezogenen Zahlen wohl nicht dieselbe Bedeutung haben, die ihnen sonst zukommt, da es sich um Thiere handelt, deren Körpersubstanz aus sehr wechselnden, zum Theil sehr erheblichen Mengen Fett besteht. Wenn z. B. Thier Nr. I am Schluss der Mästung $6600 \mathrm{~g}$ wiegt, so sind davon vielleicht $2000 \mathrm{~g}$ Fett, also eine Substanz, welche für die Stoffwechselgrösse nicht in Betracht kommt. Wenn daher die beiden Hungerversuche (Versuch 4 und 5) pro Stunde und $\mathrm{kg}$ nahezu dieselben Zahlen für den Sauerstoffverbrauch geben, so ist das nicht etwa eine zu erwartende Uebereinstimmung, sondern eher überraschend, da es sich im Versuch 4 um ein sehr fettes, im: Versuch 5 um ein ganz mageres Thier handelt (Thier Nr. II). Auf Kilogramm und Stunde gerechnet hätte man daher für Versuch 4 eine erheblich kleinere Zahl erwarten dürfen als für Versuch 5. Der Umstand, dass der Versuch 4 bei einer um ca. $4^{1 / 2^{0}}$ niedrigeren Temperatur stattfand, ist hier vielleicht von Einfluss gewesen. Möglich wäre es aber auch, dass' es sich um individuelle Verschiedenheiten der Stoffwechselgrösse handelt.

Aus der Fütterungs- und Körpergewichtstabelle für Thier Nr. I (S 360) ging hervor, dass das Thier in den vier auf die Mästungszeit folgenden Tagen, 9. bis 12. December, mit der $\mathrm{Hälfte} \mathrm{des} \mathrm{zuletzt}$ gereichten Futters sein Gewicht behauptete. Zur Erreichung der hohen Werte für den respiratorischen Quotienten musste also das kohlehydratreiche Futter etwa auf das Doppelte des Bedarfs gesteigert werden; das ist in guter Uebereinstimmung mit unserer S. 359 aus theoretischen Erwägungen hergeleiteten Bemerkung, dass eine. Zulage von mindestens $100 \%$ des Bedarfes erforderlich sei, 
um bei Mästung mit Kohlehydraten den respiratorischen Quotienten bis zum Werthe 1,33 in die Höhe zu treiben.

\section{Ergebnisse.}

Durch Mästenvon ausgewachsenen mageren Gänsen mit kohlehydratreichem Futter in grossem Ueberschuss kann man den respiratorischen Quotienten dieser Thiere dauernd über die Einheit beträchtlich hinaustreiben. Die hohen Werthe des Quotienten sind bedingt durch das Ansteigen der ausgeschiedenen Kohlensäure, nicht durch Abnehmen des verbrauchten Sauerstoffes. Das Anwachsendes respiratorischen Quotienten über das bei Verbrennung der Körpersubstanz mögliche Maass (die Einheit) hinaus beweist, dass die Umbildung von Kohlehydrat zu Fett im thierischen Körper mit einer Abspaltung von Kohlensäure verbunden ist.

Als nebenher gewonnene Ergebnisse darf ich noch hinzufügen:

1. Die mit Roggenmehl gemästeten Gänse zeigten auch auf der stärksten Höhe der Verdaungsthätigkeit keine mit Sicherheit nachweisbare Ausscheidung von brennbaren Gasen.

2. Die milchweisse Farbe des Blutserums, die bei Mastgänsen häufig beobachtet worden ist, beruht auf einer Fettemulsion von äusserster Feinheit: dieselbe verschwindet, sobald das Thier einige Tage hungert, sie tritt überhaupt nicht auf, wenn das Thier mit fettfreier, aber kohlehydratreicher Nahrung gemästet wird. Die Ursache des Fettes im Serum darf also wahrscheinlich nicht im neugebildeten Fett des Thieres, sondern im Fett der Nahrung gesucht werden.

Herrn Professor Pflüger spreche ich am Schluss dieser Arbeit für die mannigfaltige Hülfe und Anregung, die er mir während derselben zu Theil werden liess, meinen herzlichsten Dank aus. 